\title{
Utjecaj Narodne knjižnice na kvalitetu života nezaposlenih građana Influence of the Public Library on Unemployed Citizens' Quality of Life
}

\author{
Andreja Zubac ${ }^{1}$, Ana Barbarić ${ }^{2}$ \\ ${ }^{1}$ Srednjoškolski đački dom Osijek, Hrvatska / High school dormitory Osijek, Croatia \\ zubac.andreja@gmail.com \\ ${ }^{2}$ Sveučilište u Zagrebu, Filozofski fakultet, Zagreb, Hrvatska / University of Zagreb, Faculty of Humanities and Social Sciences, \\ Zagreb, Croatia \\ abarbari@ffzg.hr
}

\section{Informacije o članku / Article Info}

Primljen / Received 13. 7. 2021.

Prihvaćen / Accepted 5. 10. 2021.

Dostupan online / Available online: 1. 12. 2021.

\section{Ključne riječi / Keywords}

narodne knjižnice, potrebe nezaposlenih građana, kvaliteta života, Osječko-baranjska županija

public libraries, needs of unemployed citizens, quality of life, Osijek-Baranja County

\section{Sažetak / Abstract}

Cilj je rada predstaviti rezultate istraživanja o potrebama nezaposlenih građana Osječko-baranjske županije u svrhu unapređenja spoznaja o poboljšanju službi, usluga, programa i aktivnosti narodnih knjižnica te utjecaja na kvalitetu života nezaposlenih građana. Istraživanje je provedeno kvantitativnom metodom slučajnog uzorka ( $N=$ 250). U članku je prikazana slika stanja prije globalne zdravstvene pandemije COVID-19, krize koja je utjecala na cijeli svijet. Prikupljeni podaci statistički su obrađeni u Statističkom paketu za društvene znanosti primjenom opisne i korelacijske analize između dvije skupine varijabli te su izraženi u postotcima. Najvažniji rezultati istraživanja pokazali su da ispitani građani imaju potrebu za učenjem u sastavu cjeloživotnog obrazovanja, ali da su se, s druge strane, u najvećem ukupnom postotku na ponuđene potrebe u knjižničnom prostoru, izjasnili da nemaju potrebe.

Najizraženije potrebe ispitanih građana su potrebe za učenjem engleskoga i njemačkoga jezika; računalnim i tehničkim vještinama, potreba za usavršavanjem komunikacijskih vještina; usavršavanjem dodatnih socijalnih vještina kroz timski rad, upoznavanjem pravila poslovnog bontona, stjecanjem organizacijskih vještina, promocijskih vještina, učenjem neverbalne komunikacije ili govora tijela. Rezultat istraživanja pokazao je da, unatoč tomu što je dio ispitanika $(41,6 \%)$ član narodne knjižnice, i dalje ima različite potrebe u sastavu cjeloživotnog obrazovanja, a njihova im narodna knjižnica ne pruža mogućnost ispunjavanja. Pokazao je i to da nisu sve narodne knjižnice u Osječko-baranjskoj županiji otvorene za sve korisnike. Nezaposleni, društveno isključeni građani mišljenja su da narodna knjižnica može pomoći u razvoju zajednice, ali ne i nezaposlenima.

The aim of this paper is to present the results of the research on the needs of unemployed citizens in the Osijek-Baranja County with the purpose of improving the knowledge of advancing the services, programs, and activities of public libraries, as well as the quality of life of unemployed citizens. Research was conducted using the random sampling method $(\mathrm{N}=250)$. The article presents a picture of the situation before the global COVID-19 health pandemic, the crisis that affected the whole world. The collected data was statistically analyzed in SPSS, the Statistical Package for Social Sciences, using correlation and descriptive analysis on two groups and was thereafter expressed in percentages. The most important results of the research showed that the selected citizens have a need for lifelong learning, but that at the same time the largest percentage of them do not have the need to fulfill the named needs in a library space.

Most pronounced needs of tested citizens are the needs to learn English and German; computer and technical skills, the need to perfect communication skills; perfecting additional social skills through teamwork, familiarizing oneself with workspace etiquette, gaining organizational skills, promotional skills, learning nonverbal communication or body language. The results show that public libraries do not allow a portion of the subjects $(41.6 \%)$ to fulfill their needs, despite them having a membership to the public library and having different needs for lifelong learning. Likewise, results show that not all public libraries within the Osijek-Baranja County are open to all users. Socially excluded unemployed citizens believe that the public library can help develop communities and unemployed citizens alike. 


\section{Uvod}

Istraživanja pokazuju da u drugom desetljeću 21. stoljeća uloga narodne knjižnice sve više postaje partnerska i posrednička što je jasno izraženo kod pomaganja društveno isključenim građanima pri ispunjavanju njihovih potreba unutar zajednice $u$ kojoj obitavaju jer su narodne knjižnice otvorene za sve (Scott 2011; Slatter i Howard 2013; Mastalio 2010; James V. Brown Library 2017; ALIA 2014). Mnogi okolnosni čimbenici (postojanje objekata, način financiranja, broj i kompetencije zaposlenika, prostor, opremljenost, tehnička infrastruktura, službe i usluge, vlastiti angažman, marketing, menadžment, svijest građana, političke odluke) utječu na partnersku i posredničku ulogu narodne knjižnice. $\mathrm{Na}$ žalost, okolnosni čimbenici mogu dovesti i do izostanka inkluzivnog i kohezivnog knjižničnog poslovanja što nije u skladu s ulogom knjižnice da bude otvorena za sve, ni IFLA/UNESCO-ovim Manifestom $(1994,251)$ u kojem službe i usluge trebaju biti jednako dostupne svim skupinama ljudi. Peterman i Williment (2013) tvrde da su narodne knjižnice trenutno samo naizgled otvorene za sve. Skrzeszewski i Cubberley $(1997,326)$ uočavaju da su se knjižnice usredotočile samo na jedan resurs zajednice - informaciju. Tvrdnja je u velikoj mjeri i danas točna. $\mathrm{Wu}(2018)$ ističe da je funkcija narodnih knjižnica: obrazovna, informacijska, rekreativna, zaštićujuća / čuvateljska i kulturna. U sastavu te funkcije, od narodnih se knjižnica očekuje da čine sve za pojedinca i društvo, posebice unutar kišobrana društvene inkluzije. Stoga, autorice ovoga rada sa sigurnošću tvrde da je neophodno prvo identificirati potrebe i zadovoljstvo narodnom knjižnicom pa tek onda krenuti s nuđenjem različitih vrsta usluga jer knjižnične usluge bazirane samo na besplatnom pristupu internetu i računalu u suvremenom društvu više nisu dovoljne za osobni rast i razvoj građanina te širi razvoj zajednice. To znači da narodne knjižnice moraju proširiti svoje službe, usluge, programe i aktivnosti da bi doprinijele održivom društvenom razvoju.

O pitanju potreba građana u zajednici, Zubac (2019, 63) kaže: "Svaki čovjek ima različite potrebe za nečim, stoga u kontekstu potreba društveno isključenih građana, svaki građanin ima drukčiju knjižničnu potrebu, a u skladu s njom drukčije se ponaša."

Unutar konteksta suvremenog društva, koje je u svojoj naravi informacijsko-tehnološko, inkluzivno, kohezivno, uz praksu narodnih knjižnica (aktivnosti, vještine i procesi), neizostavni su koncepti nova ekonomija, društvena pravda, ljudski kapital, društveni kapital jer se u poslovanju međusobno isprepliću pa u nastavku slijedi njihovo detaljnije pojašnjenje.

U kontekstu nove ekonomije, Zubac (2019, 50) kaže da se njezin uspjeh temelji na nematerijalnoj

\section{Introduction}

Research shows that the purpose of public libraries in the second decade of the twenty first century became more and more intermediary and that of a partner; being institutions open to all, this partnership role is clearly expressed in helping socially excluded citizens fulfill their needs within the communities they inhabit (Scott, 2011; Slatter and Howard 2013; Mastalio 2010; James V. Brown Library 2017; ALIA 2014). Many circumstantial factors (the existence of the institution, its funding, the number and competencies of its employees, the space, equipment, technical infrastructure, services, their own engagement, marketing, management, citizens' awareness, political decisions) influence the intermediary and partnership roles of public libraries. Unfortunately, circumstantial factors can lead to the absence of conducting library business inclusively and cohesively, which is against the open to all role of libraries, as well as the ILFA/UNESCO Manifesto (1994, 251), which states that all services need to be equally available to all groups of people. Peterman and Williment (2013) claim that libraries are only seemingly open to everyone. Skrzeszewski and Cubberley $(1997,326)$ note that libraries today focus only on providing one singular resource to the community - information. The same claim is largely true today. $\mathrm{Wu}$ (2018) points out that the library has an educational, informational, recreational, protective, and cultural function. Within that function, libraries are expected to do everything for the individual as well as society at large, especially within the umbrella of social inclusion. Therefore, the authors of this article claim with certainty that it is essential to first identify the needs and satisfaction with public libraries before starting to offer various services. Nowadays, library services based solely on free internet and computer access are not enough to aid personal and communal growth. Thus, libraries must expand their services, programs, and activities to contribute to sustainable societal development.

When it comes to the needs of citizens in a community, Zubac $(2019,63)$ states: "Every human has different needs, therefore in the context of the needs of socially excluded citizens, each citizen has a different library need, and acts differently in line with it." Within the context of the practices of public libraries (activities, skills, and processes), and of contemporary society, which is in its nature informationally technological, inclusive, cohesive, concepts such as new economy, social justice, human capital, and social capital are indispensable as they overlap in business. What follows are explanations of said concepts.

In the context of new economy, Zubac $(2019,50)$ says that its success is based on immaterial assets, i.e. the intellectual knowledge of citizens, its inno- 
imovini, tj. intelektualnom znanju građanina, njegovoj inovativnosti i kreativnosti te informaciji koju građanin posjeduje, koju uz pomoć globalne informacijsko-komunikacijske tehnologije i interneta može dobro unovčiti ili samostalno pokrenuti vlastitu (manju) tvrtku koja će mu donijeti zaradu.

Šućur (2016) ističe da je koncept društvene/socijalne pravde neodređeni koncept te da je socijalnu pravdu teško jednoznačno definirati. Mišljenja je da se ovaj koncept često svodi na ideju da svi u društvu trebaju imati jednake mogućnosti/mogućnosti za život (engl. fair play). Ističe i to da je socijalna pravda šira od pravne pravde (jednakost pred zakonom) i pokriva sve relevantne sfere društvenog života te da se posebno odnosi na problem ekonomskih i socijalnih nejednakosti.

Vujčić (2016) u ljudski kapital uključuje: obrazovanje, iskustvo, obučavanje, inteligenciju, ali i radne navike, inicijativnost, vjerodostojnost i dr. U skladu s tim, Zubac $(2019,41)$ uviđa da se društveni kapital odnosi na ukupnost postupaka kojima teži i koje poduzima određena zajednica u okružju u kojemu djeluje. Stoga je cjeloživotno učenje integrirani pojam koncepata ljudskog i društvenog kapitala. $\mathrm{Na}$ društveni kapital izravno utječe nova ekonomija koja je usko povezana s obrazovanjem te društvena pravda, tj. nepravda.

Šporerina $(2004,175)$ tipologija koncepta društvene isključenosti odnosi se na: nezaposlenost, siromaštvo, nejednakost i slabiji položaj ili deprivaciju unutar nekog dijela zajednice.

Lloyd $(2010,111)$ je mišljenja da je jako malo provedenih istraživanja na temu informacijske pismenosti u narodnim knjižnicama i krajoliku zajednice jer se čini da postoji nedostatak dogovorenih standarda ili okvira za rad te da postoje i neke nejasnoće o ulozi knjižničara u tom procesu.

"Da bi nezaposleni građanin ostvario profesionalni napredak na tržištu rada, nužno je da bude u korak s promjenama u društvu (tečajevi, hobiji, samoukost, radno iskustvo koje ne mora nužno biti u struci). Cjeloživotno učenje (kao dio formalnog, neformalnog i informalnog obrazovanja) može mu pomoći u vlastitoj samoodrživosti, konkurentnosti i (mogućoj) zapošljivosti u suvremenom (informacijsko-tehnološkom te inkluzivnom i kohezivnom) društvu, kao i u obrazovanju za rad. (...) Kod nezaposlenih građana cjeloživotno učenje postaje potreba, tj. nužnost." (Zubac 2019, 43).

Narodne knjižnice, kao obrazovna, kulturna, društvena i informacijska središta, mogu i moraju utjecati na oblike informacijskog ponašanja svojih korisnika kroz ispunjavanje zahtjeva i zadovoljavanje njihovih potreba neovisno o dobi, spolu, rasi i dr. (Zubac 2019, 59). vation, creativity and the information that a citizen possesses, which can be monetized or be used to start up a profitable smaller business of one's own thanks to the global information-communicational technology.

Šucur (2016) points out that the concept of social justice is undetermined and difficult to singularly define. He is of the opinion that this concept is commonly reduced to the idea that everyone in a given society should have equal opportunities (fair play). Furthermore, he believes that social justice is a wider term than legal justice (equality before the law) and covers all spheres of social life, but refers to the problem of economic and social inequality in particular.

For Vujčić (2016) human capital includes education, experience, training, and intelligence, but also work habits, initiative, trustworthiness, etc. Zubac $(2019,41)$ thinks social capital refers to the totality of actions undertaken and sought to undertake by a certain community in its environment. Lifelong learning is therefore an integration of the concepts of human and social capital. New economy has a direct influence on social capital, which is closely connected to education and social (in)justice.

Šporer's $(2004,175)$ typology of the concepts of social exclusion refers to unemployment, poverty, inequality and a weaker position or deprivation within some part of a community.

Lloyd $(2010,111)$ is of the opinion that there are few studies done on the topic of informational literacy in public libraries and the environment of a community, indicated by a lack of uniform standards or framework leading to uncertainties about the role of a librarian as well as their role within the process.

"In order to accomplish professional progress on the labor market, the unemployed citizen necessarily needs to keep up with social changes (courses, hobbies, self-teaching, work experience outside one's field). Lifelong learning (as a part of formal, non-formal, and informal education) can help them in their own self-sustainability, competitiveness and (possible) employability in the contemporary (informationally technological, inclusive and cohesive) society, as well as educating for work. (...) For the unemployed citizen lifelong learning becomes a need, i.e. a necessity" (Zubac 2019, 43).

As an educational, cultural, social, and informational center, public libraries can and should influence the informational behavior of its users by fulfilling requests and satisfying their needs, regardless of age, sex, race, etc. (Zubac 2019, 59).

\section{Methodology}

The aim of this study is to research the needs of unemployed citizens in the context of lifelong learning 


\section{Metodologija}

Cilj istraživanja bio je istražiti potrebe nezaposlenih građana u kontekstu cjeloživotnog obrazovanja u okviru zadaća narodne knjižnice u svrhu unapređenja spoznaja o poboljšanju službi, usluga, programa i aktivnosti narodnih knjižnica te utjecaja na kvalitetu života nezaposlenih građana. U članku se autorice ograničavaju na sliku stanja prije globalne zdravstvene pandemije COVID-19 i krize koja je utjecala na cijeli svijet (od 2020. godine, a traje sve do danas) jer se u novonastaloj situaciji promijenila stopa nezaposlenosti na globalnoj, makro i mikro razini kao i uloga narodnih knjižnica. U Osječkobaranjskoj županiji (Hrvatska) djeluje ukupno deset samostalnih narodnih knjižnica.

Instrument je anketa.

Postupak: istraživanje je provedeno kvantitativnom metodom slučajnog uzorka $(\mathrm{N}=250)$ u Osječko-baranjskoj županiji 2017. što znači da su rezultati relevantni za primjenu na cijeloj populaciji.

Element potreban za procjenu istraživanja je broj nezaposlenih stanovnika u ovoj županiji. Registrirani statistički podaci za 2017. godinu su 23453 nezaposlene osobe (Hrvatski, 2017).

Anketiranje je provedeno pri Zavodima za zapošljavanje u Osječko-baranjskoj županiji na ciljanoj skupini nezaposlenih građana u studenom 2017. godine. Jedna od autorica ovoga članka osobno je anketirala nezaposlene građane.

Prikupljeni podaci statistički su obrađeni u Statističkom paketu za društvene znanosti primjenom opisne i korelacijske analize između dvije skupine varijabli te su izraženi u postotcima.

Hipoteza je: Nezaposleni građani imaju različite potrebe za cjeloživotnim obrazovanjem u knjižničnom okružju.

\section{Rezultati i rasprava}

\subsection{Sociodemografski pokazatelji}

Iz rezultata istraživanja vidljivo je da $54,8 \%$ ispitanika živi u gradu, a 45,2 \% ispitanika živi na selu u Osječko-baranjskoj županiji (Hrvatska). U istraživanju je sudjelovalo 62,4 \% žena i 37,6 \% muškaraca pa nije moguća detaljnija statistička unakrsna usporedba u odnosu na spol jer omjeri nisu približno jednaki, ali jest u odnosu na starosnu životnu dob (od 15. do 67. godine). ${ }^{1}$ Rezultat istraživanja iz ukupnog udjela ispitanika pokazao je da je najveća dugoročna nezaposlenost vidljiva kod građana sa srednjom (trogodišnjom i četverogodišnjom) školom $-62,8 \%$, slijede ih fakultetski obrazovani

Dobna granica zaposlenja u Hrvatskoj. Prema Eurostatu (2017) dobna granica je od 15. do 74. godine. within the framework of the duties of public libraries in order to improve the knowledge of advancing the services, programs, and activities of public libraries, as well as the quality of life of unemployed citizens. In the article, the authors are limited to the situation before the global COVID-19 pandemic and the crisis that affected the whole world (2020 - until today) because the unemployment rate has since changed on a global, macro-, and micro-level as well as the role of public libraries.

In the Osijek-Baranja County in Croatia there are ten independent public libraries.

The instrument of the research is a questionnaire.

Procedure: the research was conducted using the quantitative method of random sampling $(\mathrm{N}=250)$ in the Osijek-Baranja County in 2017, meaning the results are representative for the same.

The element needed to estimate the survey is the number of unemployed residents in this county. Registered statistics for 2017 are 23,453 unemployed persons (Hrvatski 2017). The survey was conducted at the Employment Bureaus in OsijekBaranja County on the target group of unemployed citizens in November 2017. One of the authors of this article personally interviewed unemployed citizens.

The collected data was statistically analyzed in SPSS, the Statistical Package for Social Sciences, using correlation and descriptive analysis on two groups and was thereafter expressed in percentages. The hypothesis is: unemployed citizens have differing needs in lifelong learning in the library environment.

\section{Results and discussion}

\subsection{Sociodemographic indicators}

The research shows that $54.8 \%$ of subjects live in the city, while $45.2 \%$ live in villages within the Osijek-Baranja County in Croatia. Due to the uneven distribution, a more detailed statistical crossreferencing when it comes to sex is impossible since $62.4 \%$ of the participants were women and $37.6 \%$ men. Such an analysis was possible for age (from 15 to 67 years). ${ }^{1}$ Results of the research shows that unemployment is highest for citizens who finished high school (three and four-year) $-62.8 \%$, followed by citizens with a university education $-24.8 \%$, citizens with a college education $-6.8 \%$, and finally, citizens with elementary school education $-5.6 \%$.

The large majority of participants, $90.4 \%$, live with another person who is employed which somewhat makes things easier for them, while only $9.6 \%$ live alone.

Age limit of employment in Croatia. According to Eurostat (2017) the age limit is from 15 to 74 years old. 
građani $-24,8 \%$, potom građani s višom školom $6,8 \%$, te $5,6 \%$ s osnovnom školom.

Od ukupnog djela, 90,4\% ispitanih građana živi u zajedničkom kućanstvu s drugom osobom koja je zaposlena, što im donekle olakšava trenutno egzistencijalno pitanje, a 9,6\% živi samo.

\subsection{Cjeloživotno obrazovanje i narodne knjižnice}

Rezultati provedenog istraživanja pokazali su da $62,4 \%$ građana ima potrebu za cjeloživotnim obrazovanjem, dok ih $37,6 \%$ nema. S obzirom na promjenjivost i dinamičnost tržišta rada, ovo je razuman pokazatelj. U odnosu na starosnu dob vidljivo je da ispitani građani od 18. do 40. godine u najvećem postotku imaju takvu potrebu jer oni u tim godinama najčešće i dobivaju svoja prva stalna zaposlenja te imaju potrebu za dokazivanjem i opstankom u njemu - u najvećem postotku žene. Upravo u toj dobnoj skupini najviše je nezaposlenih građana sa završenom srednjom (trogodišnjom i četverogodišnjom) školom te fakultetski obrazovanih građana. Slijede ih i ostale dobne skupine od 41 do 50 , od 51 do 60 godina. Vidljivo je da potrebe imaju i građani iz dobne skupine od 61. do 67. godine starosne dobi.

U kontekstu osjećaja potrebe za podupiranjem osobnog obrazovanja na cjelovitom uzorku usporedna korelacijska analiza starosne dobi ispitanika pokazuje da u dobnoj skupini od 61 do 67 godina 3,6\% ispitanih građana ne osjeća potrebu za podupiranjem osobnog obrazovanja, dok ih $0,8 \%$ osjeća. U dobnoj skupini od 51 do 60 godina $4,0 \%$ ispitanih ne osjeća potrebu za podupiranjem osobnog obrazovanja, dok ih $6,0 \%$ osjeća. U dobnoj skupini od 41 do 50 godina $7,2 \%$ ne osjeća potrebu za podupiranjem osobnog obrazovanja, dok ih $10,0 \%$ osjeća. U dobnoj skupini od 30 do 40 godina 10,0 $\%$ ne osjeća potrebu za podupiranjem osobnog obrazovanja, dok ih $21,6 \%$ osjeća. U dobnoj skupini od 18 do 29 godina $11,6 \%$ ne osjeća potrebu za podupiranjem osobnog obrazovanja, dok ih $23,6 \%$ osjeća potrebu. U dobnoj skupini od 18 godina starosne dobi $1,2 \%$ ispitanika ne osjeća potrebu, dok ih $0,4 \%$ osjeća.

Rezultati su pokazali da je od 18. do 40. godine više onih ispitanika koji imaju potrebu za cjeloživotnim obrazovanjem od onih koji nemaju.

Da bi potakli zapošljivost građana, Europska komisija (Commission 2015), UN u Agendi 2030. (Narodi 2015) i UNESCO (2014) u Programu globalnog razvoja dugi niz godina potiču važnost cjeloživotnog obrazovanja i kompetentnosti na tržištu rada svih građana, posebice odraslih. Europska komisija vidi javne i/ili narodne knjižnice kao suradnike i partnere u provođenju europskih projekata obrazovanja odraslih (starije osobe, osobe u gospodarski nepovoljnom položaju i nezaposlene).

\subsection{Lifelong learning and public libraries}

The study showed that $62.4 \%$ of citizens have a need for lifelong learning, while $37.6 \%$ do not. Considering the instability and mutability of the labor market, this is a reasonable indicator. Age-wise, the subjects aged 18 to 40 years old account for the highest percentage of those with such a need, since these are these years when one gets their first permanent employment, leading to the need to prove oneself and survive in the work environment women represent the highest percentage. That is the same age range where there is the highest percentage of unemployed citizens with a finished (three or four-year) high school or with a university degree. These are then followed by the age ranges of 41 do 50 years old, and 51 to 60 . Noticeably, citizens aged 61 to 67 also have such needs.

When it comes to the need to support one's own personal education, comparative correlative analysis of the subjects' ages shows that $3.6 \%$ of participants aged 61 to 67 do not feel the need to do so, while $0.8 \%$ feel it. In the age range 51 to $60,4.0 \%$ of participants do not feel the need to support their own personal education, while $6.0 \%$ does. Of the participants aged 41 to $50,7.2 \%$ do not feel the need to support their own education, while $10.0 \%$ does. In the age range 30 to $40,10.0 \%$ do not feel the need to support their own education, while $21.6 \%$ does. Of the participants aged 18 to 29 years old, $11.6 \%$ do not feel the need to support their own education, while $23.6 \%$ does. And finally, of the participants aged 18 years old, $1.2 \%$ do not feel such a need, while $0.4 \%$ does.

Results show that there are more participants aged 18 to 40 who do feel the need for lifelong learning than those who do not.

In order to stimulate the employability of citizens, the European Commission (2015), the UN in Agenda 2030 (2015), and UNESCO (2014) in the Global development program point out the importance of lifelong learning and competency on the labor market for all citizens, but especially for adults. The European Commission sees public libraries as partners and collaborators in realizing European projects for the lifelong learning of adults (the elderly, persons in economically unfavorable positions, and the unemployed).

The European Commission (2018) has also developed EntreComp - The European Entrepreneurship Competence Framework. Additionally, the Commission offers a comprehensive description of the knowledge, skills, and opinions citizens require to become entrepreneurial and create financial, cultural, and social value for others. The Framework (McCallum et al. 2018) identifies three key fields (Ideas and Opportunities, Resources, Into Action), which are further divided into fifteen competences 
Europska komisija (European Commision 2018) razvila je i EntreComp - Europski referentni okvir kompetencija za poduzetništvo, a uz njega nudi i sveobuhvatan opis znanja, vještina i stavova potrebnih građanima da bi bili poduzetni te stvorili financijsku, kulturnu i društvenu vrijednost za druge. Okvir (McCallum et al. 2018) identificira 3 ključna područja (Ideje i prilike, Resursi, Unutar djelovanja) iz kojih proizlazi 15 kompetencija (Brljanje mogućnostima, ${ }^{2}$ Kreativnost, Vizija, Vrednovanje ideja, Etičko i održivo razmišljanje, Samosvijest $i$ samoučinkovitost, Motivacija i ustrajnost, Mobilizacija resursa, Financijska i ekonomska pismenost, Mobiliziranje drugih; Poduzimanje inicijative, Planiranje i upravljanje, Nošenje s nesigurnošću, dvosmislenosti i rizikom, Suradnja s drugima, Učenje kroz iskustvo).

"Da bi nezaposleni građanin ostvario profesionalni napredak na tržištu rada, nužno je da bude u korak s promjenama u društvu (tečajevi, hobiji, samoukost, radno iskustvo koje ne mora nužno biti u struci). Cjeloživotno učenje (kao dio formalnog, neformalnog i informalnog obrazovanja) može mu pomoći u vlastitoj samoodrživosti, konkurentnosti i (mogućoj) zapošljivosti u suvremenom (informacijskotehnološkom te inkluzivnom i kohezivnom) društvu, kao i u obrazovanju za rad. Svrha cjeloživotnog učenja je u pomaganju građaninu da ostane aktivan u društvu kroz nove ciljeve koji će pridonijeti kvaliteti njegova života." (Zubac 2019, 43). Ono što ipak zabrinjava jest primjetna činjenica da je veliki udio ispitanika, fakultetski obrazovanih građana, drugi u nizu po nezaposlenosti.

Načelno gledano u kontekstu poslovanja narodnih knjižnica vidljivo je da su povećale opseg svojih službi i usluga u svijetu, a samo knjižničarstvo je prema Hibertu postalo društveno odgovorno, kritičko, progresivno i radikalno. Hibert naglašava i da su u tom kontekstu učenje, znanje i društvena odgovornost bit knjižničarstva 21 . stoljeća, a misija knjižničara je kreiranje znanja u lokalnim zajednicama (Hibert 2012). Drugim riječima, možemo zaključiti da je knjižnična struka i knjižnična djelatnost postala imperativ za stvaranje podloge i razvijanje cjeloživotnog obrazovanja namijenjenoga svim vrstama korisnika, i to po mogućnosti besplatno ili uz minimalnu naknadu. Istraživanja Zubac (2019) i Huysmans i Oomes (2013) pokazala su da je narodna knjižnica u 21. stoljeću uz kulturnu, društvenu, obrazovnu i informacijsku, dobila i ekonomsku ulogu te da kroz spomenute uloge knjižnice mogu i moraju utjecati na kvalitetu života nezaposlenih,

To znači da građanin treba upotrijebiti maštu i vlastitu sposobnost prepoznavanja mogućnosti za stvaranje vrijednosti kroz istraživanje društvenog, kulturnog i ekonomskog krajolika; kroz identificiranje potreba i izazova; kroz uspostavljanje novih veza i okupljanje razbacanih elemenata krajolika da bi se stvorila mogućnost za stvaranjem novih vrijednosti.
(Spotting opportunities, ${ }^{2}$ Creativity, Vision, Valuing ideas, Ethical \& sustainable thinking, Self-awareness \& self-efficacy, Motivation \& perseverance, Financial \& economic literacy, Mobilizing others, Taking the initiative, Planning \& management, Coping with uncertainty, ambiguity \& risk, Working with others, Learning through experience).

"In order to accomplish professional progress on the labor market, the unemployed citizen necessarily needs to keep up with social changes (courses, hobbies, self-teaching, work experience outside one's field). Lifelong learning (as a part of formal, non-formal, and informal education) can help them in their own self-sustainability, competitiveness and (possible) employability in the contemporary (informationally technological, inclusive and cohesive) society, as well as educating for work. The purpose of lifelong learning is helping citizens remain active in society by finding new goals that will contribute to the quality of their lives" (Zubac 2019, p. 43). What is worrying is the fact that a large portion of the participants, citizens with a completed university education, are in second place according to unemployment.

Generally looking at the context of public libraries' business, it is visible that they have expanded their range of services throughout the world, and, according to Hibert, librarianship itself has become socially responsible, critical, progressive, and radical. Hibert highlights that learning, knowledge and social responsibility are the essence of librarianship in the $21^{\text {st }}$ century even in that context, and that its mission is creating knowledge in local communities (Hibert 2012). In other words, we can conclude that the librarian profession and activity became an imperative for creating the basis and development of lifelong learning intended for all manner of users, and if possible, offering the same for free, or with minimal payment. Research done by Zubac (2019) and Huysmans and Oomes (2013) showed that the public library in the $21^{\text {st }}$ century acquired an economic role, besides the cultural, social, educational and informational ones it already had, all of which can influence the quality of life for the unemployed, socially excluded citizens, and the community within which it operates. "Public libraries can support lifelong learning by applying to projects and programs of the European Union's structural funds. (...) Through conducting such business, they have an economic impact as well and therefore get a new role - an economic one" (Zubac 2019, 49-50).

\footnotetext{
It means that citizens should use their imagination and ability to recognize opportunities for creating values through researching social, cultural, and economic environments. They can also do it through identifying needs and challenges and through establishing new connections and by bringing together all the scattered elements of the above-mentioned environments to create new values.
} 
društveno isključenih građana, u zajednici u kojoj djeluju. "Poticanje cjeloživotnog učenja narodne knjižnice mogu postići i kroz apliciranje projektnih i programskih sadržaja za Strukturne fondove Europske unije. (...) Kroz ovakvo poslovanje one imaju i ekonomski učinak pa dobivaju novu ulogu ekonomsku." (Zubac, 2019, 49-50).

Hibert $(2018,35)$ pozivajući se na Shera (1961) u kontekstu navedenoga objašnjava: "Iznoseći svoja zapažanja o vrijednostima proučavanja historije bibliotekarstva, Jesse Shera je još prije pedeset godina napomenuo kako svaki put kada je društvo zbunjeno pitanjima u kom se smjeru hoće razvijati, funkcija biblioteke prestaje biti jasno definirana. Svaka veća promjena društvenog ideala rezultirala je mogućnostima i prilikama da se uloga i funkcije biblioteka usklađuju prema značenju informacije kao društvene potrebe."

\subsection{E-mediji}

Iz ukupnog udjela vidljivo je da se $20,0 \%$ ispitanih izjasnilo da nema pristup internetu, ali ih 80,0\% ima.

Obrada rezultata ukupnog udjela (100\%) pokazala je i da samo 2,0\% ispitanih građana ne posjeduje niti jedan uređaj s kojega bi se moglo pristupiti internetu u potencijalnoj potrazi za online informacijama. Oni su prisutni u dvije postavljene dobne skupine (od 51 do 60 godina te od 61 do 67 godina). $16,8 \%$ ispitanih (zastupljenih u svim postavljenim dobnim skupinama) posjeduje samo mobitel, dok ih $1,2 \%$ posjeduje samo računalo. S druge strane, 24,8 $\%$ ispitanih u svim postavljenim dobnim skupinama posjeduje mobitel s pristupom internetu, dok ih 5,6 $\%$ posjeduje računalo s pristupom internetu. 49,6\% ispitanika zastupljenih u svim postavljenim dobnim skupinama posjeduje mobitel s internetom i računalo s pristupom internetu (Tablica 1).

Tablica 1. Posjedovanje uređaja u odnosu na starosnu dob ispitanika

\begin{tabular}{|c|c|c|c|c|c|c|}
\cline { 2 - 7 } \multicolumn{1}{c|}{} & Mobitel & $\begin{array}{c}\text { Mobitel s } \\
\text { pristupom } \\
\text { internetu }\end{array}$ & $\begin{array}{c}\text { Osobno } \\
\text { računalo }\end{array}$ & $\begin{array}{c}\text { Osobno } \\
\text { racunalo s } \\
\text { priključkom } \\
\text { na internet }\end{array}$ & $\begin{array}{c}\text { Sve od } \\
\text { navedenog }\end{array}$ & $\begin{array}{c}\text { Ništa od } \\
\text { navedenog }\end{array}$ \\
\hline $\begin{array}{c}61-67 \\
\text { godina }\end{array}$ & 2,8 & 0 & 0 & 0 & 0 & 1,6 \\
\hline $\begin{array}{c}51-60 \\
\text { godina }\end{array}$ & 3,6 & 1,2 & 0,4 & 2 & 2,4 & 0,4 \\
\hline $\begin{array}{c}41-50 \\
\text { godina }\end{array}$ & 5,2 & 4,8 & 0 & 1,6 & 5,6 & 0 \\
\hline $\begin{array}{c}30-40 \\
\text { godina }\end{array}$ & 2,8 & 11,6 & 0,4 & 1,2 & 15,6 & 0 \\
\hline $\begin{array}{c}18-29 \\
\text { godina }\end{array}$ & 2 & 6,8 & 0,4 & 0,8 & 25,2 & 0 \\
\hline $\begin{array}{c}\text { do } 18 \\
\text { godina }\end{array}$ & 0,4 & 0,4 & 0 & 0 & 0,8 & 0 \\
\hline
\end{tabular}

Omjer navedenog rezultata $(20,0 \%: 80,0 \%)$ može biti i pokazatelj da nezaposleni, društveno isključeni, građani u pitanju pristupa internetu ne ovise isključivo o posjeti narodnoj knjižnici, unatoč tomu
Hibert $(2018,35)$ recalls Sheer (1961) when explaining: "By stating his observations on the values of studying the history of librarianship, Jesse Shera pointed out fifty years ago that whenever a society is confused by the questions of which direction to develop in, the function of a library stops being clearly defined. Any larger change in social ideals results in the possibilities and opportunities for the role and function of a library to adjust according to the meaning of information as a societal need."

\subsection{E-media}

From the total number of participants $20 \%$ said they do not have internet access, while $80 \%$ does.

Analysis of the entire sample size (100\%) showed that only $2.0 \%$ percent of them do not own a single device which could access the internet in a potential search for online information. These are present in two set age ranges (51 to 60 and 61 to 67). From all age ranges, $16.8 \%$ own only a cellphone, while $1.2 \%$ own only a computer. On the other hand, $24.8 \%$ of subjects in all age ranges own a cellphone with internet access, while $5.6 \%$ own a computer with internet access. In all the set age ranges, $49.6 \%$ own a mobile phone and a computer with internet access (Table 1).

Table 1. Ownership of devices according to age

\begin{tabular}{|c|c|c|c|c|c|c|}
\cline { 2 - 7 } \multicolumn{1}{c|}{} & Cellphone & $\begin{array}{c}\text { Cell } \\
\text { phone } \\
\text { with } \\
\text { internet } \\
\text { access }\end{array}$ & $\begin{array}{c}\text { Personal } \\
\text { computer }\end{array}$ & $\begin{array}{c}\text { Personal } \\
\text { computer } \\
\text { with } \\
\text { internet } \\
\text { access }\end{array}$ & $\begin{array}{c}\text { All of the } \\
\text { above }\end{array}$ & $\begin{array}{c}\text { None of the } \\
\text { above }\end{array}$ \\
\hline $\begin{array}{c}61-67 \\
\text { years old }\end{array}$ & 2.8 & 0 & 0 & 0 & 0 & 1.6 \\
\hline $\begin{array}{c}51-60 \\
\text { years old }\end{array}$ & 3.6 & 1.2 & 0.4 & 2 & 2.4 & 0.4 \\
\hline $\begin{array}{c}41-50 \\
\text { years old }\end{array}$ & 5.2 & 4.8 & 0 & 1.6 & 5.6 & 0 \\
\hline $\begin{array}{c}30-40 \\
\text { years old }\end{array}$ & 2.8 & 11.6 & 0.4 & 1.2 & 15.6 & 0 \\
\hline $\begin{array}{c}18-29 \\
\text { years old }\end{array}$ & 2 & 6.8 & 0.4 & 0.8 & 25.2 & 0 \\
\hline $\begin{array}{c}\text { Up to } 18 \\
\text { years old }\end{array}$ & 0.4 & 0.4 & 0 & 0 & 0.8 & 0 \\
\hline
\end{tabular}

The given ratio $(20.0 \%: 80.0 \%)$ can be taken as an indicator that unemployed, socially excluded citizens do not depend solely on visiting public libraries for internet access, despite what research in European Union member states by Quick et al. (2013) found - that the primary motive for socially excluded users' visits to public libraries was the use of a computer. Furthermore, in terms of equipment and technical structure of public libraries within this county, Martinović, Badurina and Zuzjak (2016) determined that there were not enough computers for all the citizens and their longer use of the same; additionally, they found that there are some libraries within the Osijek-Baranja County that allow free internet access. One library allows free internet access when using the library Wi-Fi on one's own comput- 
što je Quickov et al. (2013) nalaz istraživanja, proveden u zemljama članicama Europske unije, pokazao da je primarni motiv dolaska društveno isključenih korisnika u narodnu knjižnicu upravo korištenje računala.

Nadalje, u kontekstu opremljenosti i tehničke strukture u narodnim knjižnicama u ovoj županiji, Martinović, Badurina i Zuzjak (2016) utvrdili su da nema dovoljno računala za sve građane i njihovu dužu vremensku upotrebu, te da neke knjižnice u Osječko-baranjskoj županiji omogućuju besplatan pristup internetu. Kažu i da je u jednoj knjižnici internetski pristup besplatan ako korisnici koriste svoje računalo putem Wi-Fi knjižnice, ali naplaćuje se ako rade na knjižničnom računalu. Drugim riječima, to bi značilo za društveno isključene nezaposlene građane da ako nemaju novca, oni ni ne mogu koristiti internet u narodnoj knjižnici. Odnosno, oni su nepoželjni članovi narodne knjižnice.

UN (2016) su proglasile građanski pristup internetu temeljnim čovjekovim pravom. Uža digitalna prava ipak bi pravno trebale urediti zemlje i lokalne zajednice u kojima građani žive, a unutar lokalnih zajednica i narodne knjižnice, kroz otvorenu internetsku mrežu. Otvoreno pitanje ostaje što učiniti s pristupom internetu ako je knjižnica zatvorena za korisnike? Ništa. Odgovorom i dalje ostaju pogođene najranjivije skupine građana - nezaposleni koji žive sami. Pristup internetu nezaposlenim, društveno isključenim građanima može biti od koristi u praćenju natječaja za posao.

S treće strane, u hrvatskim prilikama nije svaki građanin i član narodne knjižnice jer se članarina često naplaćuje, a najranjivije skupine si to ne mogu priuštiti.

\subsection{Potrebe građana za učenjem stranih jezika $i$ sličnih komponenti}

Set pitanja vezanih uz potrebe građana u domeni učenja stranih jezika (engleskog, njemačkog, švedskog) ${ }^{3}$ i sličnoj komponenti (znakovni jezik, tj. jezik za gluhonijeme) različito se interpretiraju. U kontekstu izrečenog rezultati pokazuju da u većinskom ukupnom udjelu prevladavaju oni građani koji nemaju potrebe za učenjem stranih jezika. No, unatoč tom rezultatu, najviše građana u dobnim skupinama od 18. do 40. godine u sastavu cjeloživotnog obrazovanja ima potrebu za učenjem engleskoga jezika ili nadogradnjom postojećega znanja $(28,4 \%)$, te njemačkoga jezika $(22,0 \%)$.

Potrebe za učenjem jezika imaju i starije dobne skupine pa ova vrsta obrazovanja nikako ne bi smjela

Navedeni jezici izabrani su jer su određeno vrijeme ekonomske migracije nezaposlenih građana bile usmjerene upravo na zemlje u kojima se govore ovi jezici. Engleski i njemački jezik su jezici lingua franca. ers, while there is a fee if the library computer is used. In other words, that would mean that socially excluded, unemployed citizens cannot browse the internet in a public library unless they have money, i.e. they are undesirable members of the public library.

The UN (2016) declared internet access for citizens a basic human right. More specific digital rights need to be legally determined by the countries and local communities where the citizens live, and within those, public libraries should do the same through free internet access. It remains an open issue what to do with internet access if a library is closed to users? Nothing. The answer still has the hardest impact on the most vulnerable groups of citizens - unemployed citizens living alone. Internet access can be of use to unemployed, socially excluded citizens in keeping up with job vacancies. Finally, in Croatia, not every citizen is a member of a public library as there is usually a membership fee, which the most vulnerable groups cannot afford.

\subsection{Needs of citizens for foreign language learning and other similar components}

A set of questions about citizens' needs for foreign language learning (English, German, and Swedish) ${ }^{3}$ and similar components (sign language) were interpreted differently. Results show that the largest percentage of citizens have no need for foreign language learning. Despite that, in the age range 18 to 40 , the largest number of citizens have the need to learn or improve their knowledge of English (28.4\%) and German (22.0\%) within lifelong learning programs.

The need to learn a language is found in older age brackets as well so this kind of education cannot be neglected in public libraries. Only a small portion of subjects ( $4.8 \%$ in total, across all age ranges) feel the need to learn Swedish. This need is most pronounced in the age range of 30 to 40 , but in a significantly smaller percentage compared to the need to learn English and German. Only 8.4\% of the total number of participants expressed the need to learn sign language, mostly in the age range of 18 to 29 .

\subsubsection{English language}

Comparative correlation analysis of age range and the need to learn English within lifelong learning in libraries shows that none of the participants aged between 61 and 67 have the need to learn the English language. In the age range of 51 to $60,7.2 \%$ of participants do not feel the need, while $2.8 \%$ do.

Language selection was done based on the fact that economic migrations of unemployed citizens were for a time focused on the countries where these languages are spoken. English and German are lingua franca. 
biti zanemarena u narodnim knjižnicama. Potrebu za učenjem švedskoga jezika ima jako malo ispitanih građana (ukupno 4,8\% u svim dobnim skupinama). Potreba je također najizraženija u ispitanoj dobnoj skupini od 30 do 40 godina, ali u jako malom postotku u odnosu na potrebu za učenjem engleskoga i njemačkoga jezika. Od ukupnog udjela ispitanih, samo $8,4 \%$ ispitanih građana izjasnilo se da ima potrebu za učenjem jezika za gluhonijeme. Najviše ih je iz dobne skupine od 18 do 29 godina.

\subsubsection{Engleski jezik}

Iz usporedne korelacijske analize starosne dobi ispitanika za učenjem engleskoga jezika u sastavu cjeloživotnog obrazovanja u knjižničnom prostoru vidljivo je da u dobnoj skupini od 61 do 67 godina nitko od ispitanih nema potrebu za učenjem engleskoga jezika. U dobnoj skupini od 51 do 60 godina $7,2 \%$ ispitanih nema potrebu, a 2,8\% ima potrebu. U dobnoj skupini od 41 do 50 godina $13,2 \%$ ispitanih nema potrebu za učenjem engleskoga jezika, dok ih 4,0\% ima. U dobnoj skupni od 30 do 40 godina $19,6 \%$ ispitanih nema potrebu za učenjem engleskoga jezika, dok ih $12,0 \%$ ima. U dobnoj skupni od 18 do 29 godina $18,8 \%$ ispitanih nema potrebu za učenjem engleskoga jezika, dok ih 16,4 $\%$ ima. Rezultati pokazuju da je od 18 . do 40. godine više onih ispitanika koji imaju potrebu za učenjem engleskoga jezika u prostorima knjižnice od onih koji nemaju. U dobnoj skupini do 18 godina $0,8 \%$ ispitanih ima potrebu, a $0,4 \%$ ispitanih građana nema potrebu (Slika 1).

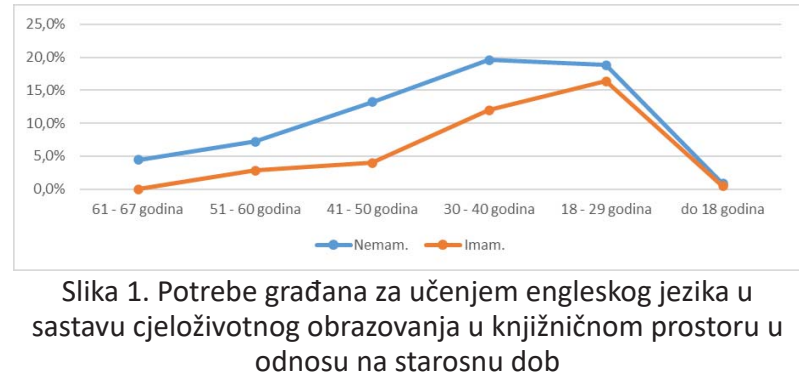

\subsubsection{Njemački jezik}

Usporedna korelacijska analiza starosne dobi ispitanika za učenjem njemačkog jezika u sastavu cjeloživotnog obrazovanja u knjižničnom prostoru u odnosu na starosnu dob pokazuje da u dobnoj skupini od 61 do 67 godina nitko od ispitanih nema potrebu za učenjem njemačkog jezika. U dobnoj skupni od 51 do 60 godina $8,0 \%$ ispitanih nema potrebu, a 2,0 $\%$ ima potrebu. U dobnoj skupni od 41 do 50 godina $13,6 \%$ ispitanih nema potrebu za učenjem njemačkog jezika, dok ih 3,6 \% ima. U dobnoj skupni od 30 do 40 godina $21,6 \%$ ispitanih nema potrebu za učenjem njemačkog jezika, dok ih $10,0 \%$ ima. U dobnoj skupni od 18 do 29 godina $22,8 \%$ ispitanih
In the age range of 41 to $50,13.2 \%$ of participants do not feel the need to learn the English language, whereas $4.0 \%$ does. In the age range of 30 to 40 , $19.6 \%$ of participants do not feel the need to learn English, and $12.0 \%$ does. In the age range of 18 to $29,18.8 \%$ of participants do not feel the need to learn English, and $16.4 \%$ does. Results show that there are more participants in the age range of 18 to 40 who do feel the need to learn English than those who do not. Of the participants aged up to 18 years old, $0.8 \%$ have the need to learn English, and $0.4 \%$ do not (Picture 1).

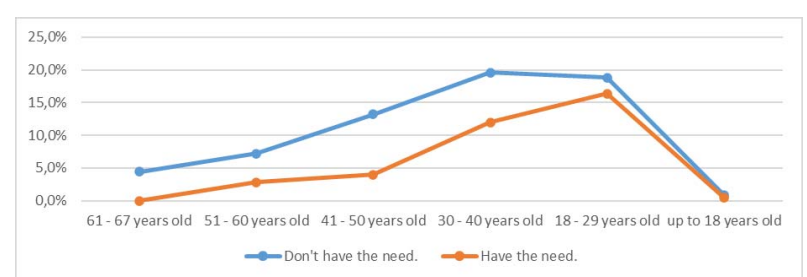

Picture 1. The needs of citizens to learn the English language within lifelong learning in libraries compared to age range

\subsubsection{German language}

Comparative correlation analysis of age range and the need to learn German within lifelong learning in libraries shows that none of the participants aged between 61 and 67 have the need to learn the German language. In the age range of 51 to $60,8.0 \%$ of participants do not feel the need, while $2.0 \%$ do. In the age range of 41 to $50,13.6 \%$ of participants do not feel the need to learn the German language, whereas $3.6 \%$ does. In the age range of 30 to 40 , $21.6 \%$ of participants do not feel the need to learn German, and $10.0 \%$ does. In the age range of 18 to $29,22.8 \%$ of participants do not feel the need to learn German, and $12.4 \%$ does. Of the participants aged up to 18 years old, $1.2 \%$ have the need to learn German, and $0.4 \%$ do not (Picture 2).

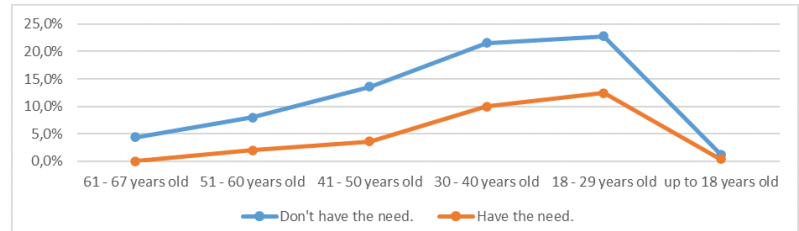

Picture 2. The needs of citizens to learn the German language within lifelong learning in libraries compared to age range

\subsubsection{Swedish language}

Comparative correlation analysis of age range and the need to learn Swedish within lifelong learning in libraries shows that none of the participants aged between 61 and 67 have the need to learn the Swedish language. In the age range of 51 to $60,9.6 \%$ of participants do not feel the need, while $0.4 \%$ do. In the age range of 41 to $50,16.8 \%$ of participants do not feel the need to learn the Swedish language, whereas $0.4 \%$ does. In the age range of 30 to 40 , 
nema potrebu za učenjem njemačkog jezika, dok ih $12,4 \%$ ima. U dobnoj skupini do 18 godina 1,2 $\%$ ispitanih ima potrebu, a $0,4 \%$ ispitanih građana nema potrebu (Slika 2).

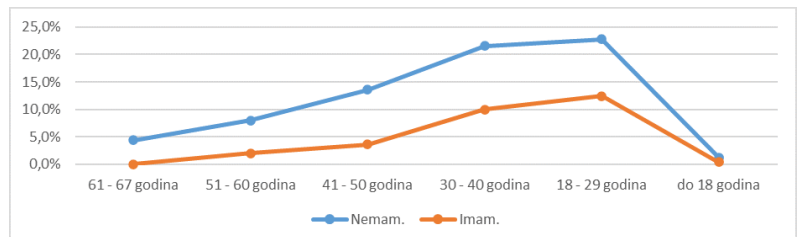

Slika 2. Potrebe građana za učenjem njemačkog jezika u sastavu cjeloživotnog obrazovanja u knjižničnom prostoru u odnosu na starosnu dob

\subsection{3. Švedski jezik}

Usporedna korelacijska analiza starosne dobi ispitanika za učenjem švedskog jezika u sastavu cjeloživotnog obrazovanja u knjižničnom prostoru u odnosu na starosnu dob pokazuje da u dobnoj skupini od 61 do 67 godina nitko od ispitanih nema potrebu za učenjem švedskog jezika. U dobnoj skupni od 51 do 60 godina $9,6 \%$ ispitanih nema potrebu, a $0,4 \%$ ima potrebu. U dobnoj skupni od 41 do 50 godina $16,8 \%$ ispitanih nema potrebu za učenjem švedskog jezika, dok ih $0,4 \%$ ima. U dobnoj skupni od 30 do 40 godina $28,8 \%$ ispitanih nema potrebu za učenjem švedskog jezika, dok ih $2,8 \%$ ima. U dobnoj skupni od 18 do 29 godina 34,0 \% ispitanih nema potrebu za učenjem švedskog jezika, dok ih $1,2 \%$ ima. U dobnoj skupini do 18 godina nitko od ispitanih $(1,6 \%)$ nema takvu potrebu.

\subsubsection{Znakovni jezik}

Usporedna korelacijska analiza starosne dobi ispitanika za učenje jezika za gluhonijeme u sastavu cjeloživotnog obrazovanja u knjižničnom prostoru pokazuje da u dobnoj skupini od 61 do 67 godina nitko od ispitanih nema potrebu za učenjem jezika za gluhonijeme.

U dobnoj skupini od 51 do 60 godina 9,2\% ispitanih nema potrebu, a $0,8 \%$ ima potrebu. $U$ dobnoj skupini od 41 do 50 godina $16,8 \%$ ispitanih nema potrebu za učenjem jezika za gluhonijeme, dok ih $0,4 \%$ ima. U dobnoj skupni od 30 do 40 godina $29,2 \%$ ispitanih nema potrebu, dok ih $2,4 \%$ ima. U dobnoj skupni od 18 do 29 godina $31,2 \%$ ispitanih nema potrebu, dok ih 4,0\% ima. U dobnoj skupini do 18 godina $0,8 \%$ nema, a $0,8 \%$ ispitanih ima takvu potrebu.

\subsection{Računalne i tehničke vještine}

U kontekstu potrebe za stjecanjem računalnih i tehničkih vještina u knjižničnom prostoru, kao jednog od bitnih čimbenika u premošćivanju digitalne nejednakosti (primjerice ECDL diploma), rezultati
$28.8 \%$ of participants do not feel the need to learn Swedish, and $2.8 \%$ does. In the age range of 18 to $29,34.0 \%$ of participants do not feel the need to learn Swedish, and $1.2 \%$ does. Of the participants aged up to 18 years old, none of the participants $(1.6 \%)$ have the need to learn Swedish.

\subsubsection{Sign language}

Comparative correlation analysis of age range and the need to learn sign language within lifelong learning in libraries shows that none of the participants aged between 61 and 67 have the need to learn sign language. In the age range of 51 to $60,9.2 \%$ of participants do not feel the need, while $0.8 \%$ do. In the age range of 41 to $50,16.8 \%$ of participants do not feel the need to learn sign language, whereas $0.4 \%$ does. In the age range of 30 to $40,29.2 \%$ of participants do not feel the need to learn sign language, and $2.4 \%$ does. In the age range of 18 to 29 , $31.2 \%$ of participants do not feel the need to learn sign language, and $4.0 \%$ does. Of the participants aged up to 18 years old, $0.8 \%$ do not have the need to learn sign language, and $0.8 \%$ do.

\subsection{Computer and technical skills}

Results show that there are more citizens who do not feel the need for gaining computer and technical skills in libraries as one of the big factors in overcoming digital inequality (e.g. ECDL certificate), than those who do feel it. Nevertheless, $26 \%$ do have such a need, especially in the age range of 18 to 40 years old, followed by citizens aged 41 to 50 . Therefore, this need should not be disregarded either.

Comparative correlation analysis of age range shows that none of the participants aged between 61 and 67 have this need. In the age range of 51 to $60,7.6 \%$ of participants do not feel the need, while $2.4 \%$ do. In the age range of 41 to $50,14.0 \%$ of participants do not feel the need to gain computer and technical skills, whereas $3.2 \%$ does. In the age range of 30 to $40,20.0 \%$ of participants do not feel this need, and $11.6 \%$ does. In the age range of 18 to $29,26.4 \%$ of participants do not feel the need to learn sign language, and $8.8 \%$ does. None of the participants aged up to 18 years old have this need (Picture 3).

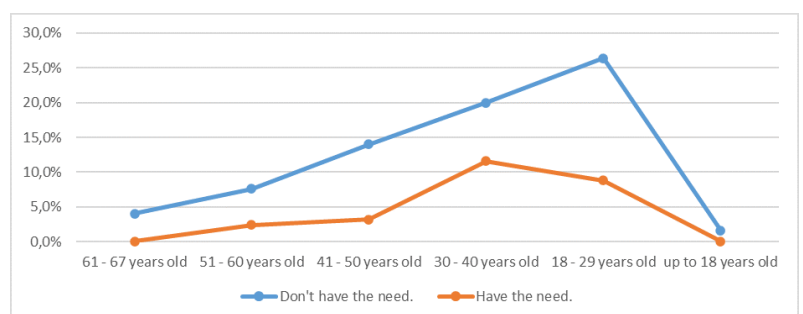

Picture 3. The needs of citizens to gain computer and technical skills within lifelong learning in libraries compared to age range 
pokazuju da prevladavaju oni građani koji nemaju potrebe za tim, ali $26 \%$ ispitanih od ukupnog udjela ima takvu potrebu, posebice u kategorijama od 18 do 40 godina, a slijede ih građani od 41 do 50 godina starosne dobi. Stoga ni ovu potrebu ne bi trebalo zanemariti.

Nadalje, usporedna korelacijska analiza starosne dobi pokazala je da u dobnoj skupini od 61 do 67 godina nitko od ispitanih nema takvu potrebu. U dobnoj skupini od 51 do 60 godina 7,6\% ispitanih nema potrebu, a 2,4\% ima potrebu. $U$ dobnoj skupini od 41 do 50 godina $14,0 \%$ ispitanih nema potrebu za stjecanjem računalnih i tehničkih vještina, dok ih 3,2 \% ima. U dobnoj skupni od 30 do 40 godina $20,0 \%$ ispitanih nema potrebu, dok ih 11,6 $\%$ ima. U dobnoj skupini od 18 do 29 godina $26,4 \%$ ispitanih nema potrebu, dok ih $8,8 \%$ ima. U dobnoj skupini do 18 godina nitko od ispitanika nema takvu potrebu (Slika 3).

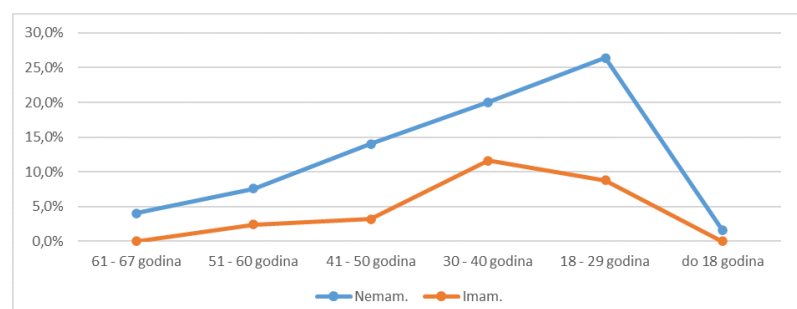

Slika 3. Potrebe građana za stjecanjem računalnih i tehničkih vještina u sastavu cjeloživotnog obrazovanja u knjižničnom prostoru u odnosu na starosnu dob

\subsection{Radionice (pretraživanje izvora na internetu, pisanje životopisa, dodatno usavršavanje u svojoj struci)}

U kontekstu potrebe za stjecanjem znanja u pitanju kvalitetnog pisanja životopisa, rezultati ukupnog udjela pokazuju da $u$ istraživanju prevladavaju oni građani koji nemaju potrebu za tim. S duge strane, $24,0 \%$ od $100 \%$ ispitanih ima takvu potrebu. Najviše građana od 18. do 29. godine u sastavu cjeloživotnog obrazovanja ima potrebu za radionicama za pisanje životopisa.

U kontekstu potrebe za dodatnim usavršavanjem u svojoj struci u knjižničnom prostoru rezultati pokazuju da u istraživanju prevladavaju oni građani koji nemaju potrebu za tim. S duge strane $36,8 \%$ od 100 $\%$ ispitanih ima takvu potrebu, i to u svim dobnim skupinama. Ova potreba najizraženija je među mladima od 18 do 29 godine života, a slijede ih odrasli od 30 do 40 godina.

Usporedna korelacijska analiza starosne dobi ispitanika u kontekstu potrebe građana za radionicama za pretraživanjem izvora na internetu u sastavu cjeloživotnog obrazovanja u knjižničnom prostoru pokazuje da u dobnoj skupini od 61 do 67 godina nitko od ispitanih nema takvu potrebu. $U$ dobnoj skupini od 51 do 60 godina $6,8 \%$ ispitanih nema potrebu,

\subsection{Workshops (searching for sources online, writing CVs, additional improvement in one's field)}

Results show that the majority of subject do not feel the need to gain the knowledge on successfully writing a CV. On the other hand, $24.0 \%$ of the total number have the need for workshops on writing CVs within lifelong learning, mostly citizens within the age range of 18 to 29 . Results show that the majority of subjects do not feel the need for additional improvement in one's field within libraries. On the other hand, $36.8 \%$ of the total number within all age ranges have this need. The need is most pronounced within young adults aged 18 to 29 years old, followed by adults aged 30 to 40 .

Correlation analysis of age range in comparison to the need to research sources online within lifelong learning in libraries shows that none of the participants aged between 61 and 67 have this need. In the age range of 51 to $60,6.8 \%$ of participants do not feel the need, while $3.2 \%$ do. In the age range of 41 to $50,13.2 \%$ of participants do not feel the need for workshops on searching for sources online, whereas $4.0 \%$ does. In the age range of 30 to $40,25.6 \%$ of participants do not feel the need for workshops on searching for sources online, and $6.0 \%$ does. In the age range of 18 to $29,28.8 \%$ of participants do not feel this need, and $6.4 \%$ does. Of the participants aged up to 18 years old, $1.2 \%$ of participants do not feel this need, while $0.4 \%$ do.

Correlation analysis of age range in comparison to the need for workshops on writing CVs within lifelong learning programs in libraries shows that none of the participants aged between 61 and 67 have this need. In the age range of 51 to $60,8.8 \%$ of participants do not feel the need, while $1.2 \%$ do. In the age range of 41 to $50,13.2 \%$ of participants do not feel such a need, whereas $4.0 \%$ does. In the age range of 30 to $40,23.6 \%$ of participants do not feel this need, and $8.0 \%$ does. In the age range of 18 to $29,24.8 \%$ of participants do not feel the need, and $10.4 \%$ does. Of the participants aged up to 18 years old, $1.2 \%$ of participants do not feel this need, while $0.4 \%$ do.

Correlation analysis of age range in comparison to the need for improving oneself within one's own field within lifelong learning programs in libraries shows that, of the participants aged between 61 and $67,4.0 \%$ do not have this need, whereas $0.4 \%$ do. In the age range of 51 to $60,7.2 \%$ of participants do not feel the need, while $2.8 \%$ do. In the age range of 41 to $50,11.2 \%$ of participants do not feel the need for improving themselves in their fields, whereas $6.0 \%$ does. In the age range of 30 to $40,20.4 \%$ of participants do not feel the need to improve themselves within their fields, and $11.2 \%$ does. In the age range of 18 to $29,19.6 \%$ of participants do not feel this need, and $15.6 \%$ does. Of the participants aged 
a 3,2 \% ima potrebu. U dobnoj skupini od 41 do 50 godina $13,2 \%$ ispitanih nema potrebu za radionicama za pretraživanjem izvora na internetu, dok ih 4,0 $\%$ ima. U dobnoj skupni od 30 do 40 godina 25,6 $\%$ ispitanih nema potrebu za radionicama za pretraživanjem izvora na internetu, dok ih 6,0 \% ima. U dobnoj skupini od 18 do 29 godina 28,8\% ispitanih nema potrebu, dok ih 6,4 \% ima. U dobnoj skupini do 18 godina $1,2 \%$ ispitanika nema takvu potrebu, a $0,4 \%$ ispitanih ima.

Usporedna korelacijska analiza starosne dobi ispitanika u kontekstu potrebe građana za radionicama za pisanje životopisa u sastavu cjeloživotnog obrazovanja u knjižničnom prostoru u odnosu na starosnu dob pokazuje da u dobnoj skupini od 61 do 67 godina nitko od ispitanih nema takvu potrebu. $U$ dobnoj skupini od 51 do 60 godina $8,8 \%$ ispitanih nema potrebu, a 1,2\% ima potrebu. U dobnoj skupini od 41 do 50 godina $13,2 \%$ ispitanih nema potrebu za radionicama za pisanje životopisa, dok ih $4,0 \%$ ima. U dobnoj skupni od 30 do 40 godina $23,6 \%$ ispitanih nema potrebu za tim, dok ih $8,0 \%$ ima. U dobnoj skupini od 18 do 29 godina 24,8\% ispitanih nema potrebu, dok ih 10,4\% ima. U dobnoj skupini do 18 godina $1,2 \%$ ispitanika nema takvu potrebu, a $0,4 \%$ ispitanih ima.

Usporedna korelacijska analiza starosne dobi ispitanika u kontekstu potrebe građana za dodatnim usavršavanjem u svojoj struci u sastavu cjeloživotnog obrazovanja u knjižničnom prostoru u odnosu na starosnu dob pokazuje da u dobnoj skupini od 61 do 67 godina 4,0\% ispitanih nema takvu potrebu, dok ih $0,4 \%$ ima. U dobnoj skupini od 51 do 60 godina $7,2 \%$ ispitanih nema potrebu, a 2,8 \% ima. U dobnoj skupini od 41 do 50 godina $11,2 \%$ ispitanih nema potrebu za dodatnim usavršavanjem u svojoj struci, dok ih $6,0 \%$ ima. U dobnoj skupni od 30 do 40 godina $20,4 \%$ ispitanih nema potrebu za dodatnim usavršavanjem u svojoj struci, dok ih 11,2 $\%$ ima. U dobnoj skupini od 18 do 29 godina 19,6 $\%$ ispitanih nema potrebu, dok ih $15,6 \%$ ima. U dobnoj skupini do 18 godina $0,8 \%$ ispitanika nema takvu potrebu, a $0,8 \%$ ispitanih ima.

\subsection{Komunikacijske vještine}

Iz rezultata istraživanja vidljivo je da potrebu za usavršavanjem komunikacijskih vještina u knjižničnom prostoru u najvećem ukupnom postotku građani nemaju, ali $27,6 \%$ od $100 \%$ ispitanih ima takvu potrebu. Ona je najviše izražena među mladima u dvije dobne skupine od 18 do 29 godine života, a slijede ih odrasli od 30 do 40 godina. U suvremenom društvu upravo je posjedovanje komunikacijskih (verbalnodiplomatskih) vještina, uz znanje, i najbitnije za prezentiranje samoga sebe i dobivanje zaposlenja.

U kontekstu potrebe građana za usavršavanjem for- up to 18 years old, $0.8 \%$ of participants do not feel this need, and $0.8 \%$ do.

\subsection{Communication skills}

Results of the research show that citizens largely do not feel the need to perfect their communication skills in libraries; still, $27.6 \%$ out of $100 \%$ do feel the need. It is most pronounced in two age ranges, that of 18 to 29 years old, and 30 to 40 . Alongside knowledge, communication (verbal-diplomatic) skills are nowadays the most important factors for presenting oneself and getting a job.

Correlation analysis of age range in comparison to the need for perfecting formal communication skills within lifelong learning programs in libraries shows that, of the participants aged between 61 and 67, none of the participants have this need. In the age range of 51 to $60,7.2 \%$ of participants do not feel the need, while $2.8 \%$ do. In the age range of 41 to 50 , $12.0 \%$ of participants do not feel the need, whereas $5.2 \%$ does. In the age range of 30 to $40,22.8 \%$ of participants do not feel the need for perfecting their formal communication skills, and $8.8 \%$ does. In the age range of 18 to $29,24.8 \%$ of participants do not feel the need, and $10.4 \%$ does. Of the participants aged up to 18 years old, $1.2 \%$ of participants do not feel this need, and $0.4 \%$ do.

\subsection{Social skills}

The set of questions related to social skills includes perfecting additional social skills through teamwork, and through learning work etiquette, additional social skills through organizational skills, perfecting additional social skills through presentation skills, and perfecting them through body language.

Out of the total sample size, $18.8 \%$ have the need for perfecting additional skills through teamwork in libraries, $18 \%$ have the need for learning work etiquette, $24.8 \%$ for perfecting additional social skills through organizational skills, $30 \%$ for perfecting them through presentation skills, and $13.6 \%$ for perfecting additional social skills in libraries through body language.

These are the most common needs of citizens necessary for a longer tenure at a position and quality everyday communication with colleagues and other persons they meet.

Comparative correlation analysis of age range and the need for perfecting additional social skills through teamwork within lifelong learning programs in libraries shows that, of the participants aged between 61 and $67,4.0 \%$ do not have this need, and $0.4 \%$ do. In the age range of 51 to $60,8.4 \%$ of participants do not feel the need, while $1.6 \%$ do. In the age range of 41 to $50,16.0 \%$ of participants do not feel the need 
malnih komunikacijskih vještina u sastavu cjeloživotnog obrazovanja u knjižničnom prostoru u odnosu na starosnu dob, usporedna korelacijska analiza pokazuje da u dobnoj skupini od 61 do 67 godina nitko od ispitanih nema takvu potrebu. U dobnoj skupini od 51 do 60 godina 7,2\% ispitanih nema potrebu, a $2,8 \%$ ima potrebu. U dobnoj skupini od 41 do 50 godina $12,0 \%$ ispitanih nema potrebu, dok ih 5,2\% ima. U dobnoj skupni od 30 do 40 godina $22,8 \%$ ispitanih nema potrebu za usavršavanjem formalnih komunikacijskih vještina, dok ih $8,8 \%$ ima. U dobnoj skupini od 18 do 29 godina $24,8 \%$ ispitanih nema potrebu, dok ih $10,4 \%$ ima. U dobnoj skupini do 18 godina $1,2 \%$ ispitanika nema takvu potrebu, a $0,4 \%$ ispitanih ima.

\subsection{Socijalne vještine}

Set pitanja vezanih uz socijalne vještine uključuje usavršavanje dodatnih socijalnih vještina kroz timski rad, kroz upoznavanje pravila poslovnog bontona, dodatnih socijalnih vještina kroz organizacijske vještine, usavršavanjem dodatnih socijalnih vještina kroz prezentacijske vještine, usavršavanjem dodatnih socijalnih vještina kroz govor tijela.

Od ukupnog udjela (100\%), 18,8\% ima potrebu za usavršavanjem dodatnih socijalnih vještina kroz timski rad u knjižničnom prostoru, $18 \%$ za upoznavanje pravila poslovnog bontona, $24,8 \%$ za dodatnim socijalnim vještinama kroz organizacijske vještine, $30 \%$ za usavršavanjem dodatnih socijalnih vještina kroz prezentacijske vještine, 13,6 \% za usavršavanjem dodatnih socijalnih vještina kroz govor tijela u knjižničnom prostoru.

Ovo su uobičajene potrebe koje su građanima neophodne za duži opstanak u poslu i kvalitetnu, svakodnevnu komunikaciju s kolegama te osobama s kojima se susreću.

U kontekstu potrebe građana za usavršavanjem dodatnih socijalnih vještina kroz timski rad u sastavu cjeloživotnog obrazovanja u knjižničnom prostoru u odnosu na starosnu dob usporedna korelacijska analiza pokazuje da u dobnoj skupini od 61 do 67 godina $4,0 \%$ ispitanih nema takvu potrebu, a 0,4 $\%$ ih ima. U dobnoj skupini od 51 do 60 godina 8,4 $\%$ ispitanih nema potrebu, a 1,6\% ima. U dobnoj skupini od 41 do 50 godina $16,0 \%$ ispitanih nema potrebu za usavršavanjem dodatnih socijalnih vještina kroz timski rad, dok ih $1,2 \%$ ima. U dobnoj skupni od 30 do 40 godina $24,8 \%$ ispitanih nema potrebu za usavršavanjem dodatnih socijalnih vještina kroz timski rad, dok ih $6,8 \%$ ima. U dobnoj skupini od 18 do 29 godina 26,4\% ispitanih nema tu potrebu, dok ih $8,8 \%$ ima. Dobna skupina do 18 godina nema takvu potrebu. for perfecting additional social skills through teamwork, whereas $1.2 \%$ does. In the age range of 30 to $40,24.8 \%$ of participants do not feel the need for perfecting additional social skills through teamwork, and $2.8 \%$ does. In the age range of 18 to $29,26.4 \%$ of participants do not feel such a need, and $8.8 \%$ does. Of the participants aged up to 18 years old, none of the participants have such a need.

Comparative correlation analysis of age range and the need for perfecting additional social skills through learning work etiquette within lifelong learning programs in libraries shows that none of the participants aged between 61 and 67 have this need. In the age range of 51 to $60,8.8 \%$ of participants do not feel the need, while $1.2 \%$ do. In the age range of 41 to $50,14.8 \%$ of participants do not feel the need for perfecting additional social skills through learning work etiquette, whereas $2.4 \%$ does. In the age range of 30 to $40,24.0 \%$ of participants do not feel this need, and 7.6\% does. In the age range of 18 to $29,28.4 \%$ of participants do not feel such a need, and $6.8 \%$ does. Of the participants aged up to 18 years old, none of the participants have such a need. Comparative correlation analysis of age range and the need for perfecting additional social skills through organizational skills within lifelong learning programs in libraries shows that none of the participants aged between 61 and 67 have this need. In the age range of 51 to $60,8.4 \%$ of participants do not feel the need, while $1.6 \%$ do. In the age range of 41 to $50,15.2 \%$ of participants do not feel this need, whereas $2.0 \%$ does. In the age range of 30 to $40,20.4 \%$ of participants do not feel this need, and $11.2 \%$ does. In the age range of 18 to $29,34.0 \%$ of participants do not feel such a need, and $9.6 \%$ does. Of the participants aged up to 18 years old, $1.2 \%$ do not feel this need, while $0.4 \%$ does.

Comparative correlation analysis of age range and the need for perfecting additional social skills through presentational skills within lifelong learning programs in libraries shows that none of the participants aged between 61 and 67 have this need. In the age range of 51 to $60,7.6 \%$ of participants do not feel the need, while $2.4 \%$ do. In the age range of 41 to $50,12.8 \%$ of participants do not feel this need, whereas $14.7 \%$ does. In the age range of 30 to $40,28.0 \%$ of participants do not feel this need, and $4.4 \%$ does. In the age range of 18 to $29,24.4 \%$ of participants do not feel such a need, and $10.8 \%$ does. Of the participants aged up to 18 years old, $1.2 \%$ do not feel this need, while $0.4 \%$ does.

Comparative correlation analysis of age range and the need for perfecting additional social skills through body language within lifelong learning programs in libraries shows that none of the participants aged between 61 and 67 have this need. In the age range of 51 to $60,9.2 \%$ of participants do 
U kontekstu potrebe građana za usavršavanjem dodatnih socijalnih vještina kroz upoznavanje pravila poslovnog bontona u sastavu cjeloživotnog obrazovanja u knjižničnom prostoru u odnosu na starosnu dob, usporedna korelacijska analiza pokazuje da u dobnoj skupini od 61 do 67 godina nitko od ispitanih nema takvu potrebu. U dobnoj skupini od 51 do 60 godina $8,8 \%$ ispitanih nema potrebu, a $1,2 \%$ ima potrebu. U dobnoj skupini od 41 do 50 godina 14,8 $\%$ ispitanih nema potrebu za usavršavanjem dodatnih socijalnih vještina kroz upoznavanje pravila poslovnog bontona, dok ih 2,4 \% ima. U dobnoj skupni od 30 do 40 godina $24,0 \%$ ispitanih nema potrebu, dok ih $7,6 \%$ ima. U dobnoj skupini od 18 do 29 godina $28,4 \%$ ispitanih nema potrebu, dok ih $6,8 \%$ ima. $\mathrm{U}$ dobnoj skupini do 18 godina nema takvih potreba.

Usporedna korelacijska analiza starosne dobi ispitanika u kontekstu potrebe građana za usavršavanjem dodatnih socijalnih vještina kroz organizacijske vještine u sastavu cjeloživotnog obrazovanja u knjižničnom prostoru u odnosu na starosnu dob pokazuje da u dobnoj skupini od 61 do 67 godina nitko od ispitanih nema takvu potrebu. U dobnoj skupini od 51 do 60 godina $8,4 \%$ ispitanih nema potrebu, a 1,6\% ima potrebu. U dobnoj skupini od 41 do 50 godina $15,2 \%$ ispitanih nema takvu potrebu, dok ih $2,0 \%$ ima. U dobnoj skupni od 30 do 40 godina $20,4 \%$ ispitanih nema potrebu, dok ih $11,2 \%$ ima. U dobnoj skupini od 18 do 29 godina 34,0\% ispitanih nema potrebu, dok ih 9,6\% ima. U dobnoj skupini do 18 godina $1,2 \%$ nema takvu potrebu, a $0,4 \%$ ima.

Usporedna korelacijska analiza starosne dobi ispitanika u kontekstu potrebe građana za usavršavanjem dodatnih socijalnih vještina kroz prezentacijske vještine u sastavu cjeloživotnog obrazovanja $u$ knjižničnom prostoru pokazuje da u dobnoj skupini od 61 do 67 godina nitko od ispitanih nema takvu potrebu. U dobnoj skupini od 51 do 60 godina 7,6 $\%$ ispitanih nema potrebu, a $2,4 \%$ ima potrebu. U dobnoj skupini od 41 do 50 godina 12,8\% ispitanih nema takvu potrebu, dok ih $14,7 \%$ ima. U dobnoj skupni od 30 do 40 godina $28,0 \%$ ispitanih nema potrebu, dok ih $4,4 \%$ ima. U dobnoj skupini od 18 do 29 godina $24,4 \%$ ispitanih nema potrebu, dok ih $10,8 \%$ ima. U dobnoj skupini do 18 godina $1,2 \%$ nema takvu potrebu, a $0,4 \%$ ih ima.

U kontekstu potrebe građana za usavršavanjem dodatnih socijalnih vještina kroz govor tijela u sastavu cjeloživotnog obrazovanja u knjižničnom prostoru u odnosu na starosnu dob usporedna korelacijska analiza pokazuje da u dobnoj skupini od 61 do 67 godina nitko od ispitanih nema takvu potrebu. U dobnoj skupini od 51 do 60 godina 9,2\% ispitanih nema potrebu, a $0,8 \%$ ima potrebu. $\mathrm{U}$ dobnoj skupini od 41 do 50 godina 14,8 \% ispitanih nema takvu potrebu, dok ih $2,4 \%$ ima. U dobnoj skupni od 30 do 40 godina $26,4 \%$ ispitanih nema potrebu not feel the need, while $0.8 \%$ do. In the age range of 41 to $50,14.8 \%$ of participants do not feel this need, whereas $2.4 \%$ does. In the age range of 30 to $40,26.4 \%$ of participants do not feel this need, and $5.2 \%$ does. In the age range of 18 to $29,30.4 \%$ of participants do not feel such a need, and $4.8 \%$ does. Of the participants aged up to 18 years old, $1.2 \%$ do not feel this need, while $0.4 \%$ does.

Communication can be used to realize oneself (thoughts, feelings, speech), send a message, realize a goal, get feedback from others so we conclude that communication skills are closely connected to social skills. In essence, there are two general kinds of communication (verbal and nonverbal). Communication can be interpersonal, intrapersonal, group, public, mass and intercultural (Reardon 1998). Additionally, we can use interpersonal communication to give, ask, and get love and attention, the respect of others, trust, support, understanding, encouragement from the people around us, and responsibility (the feeling of self-actualization) (Brajša 2013).

\subsection{Library membership and citizens' opinions on its helpfulness}

Results show that, of the total sample size, $58.4 \%$ of participants are not library members, i.e. they do not have a library membership, while $41.6 \%$ are.

Comparative correlation analysis of age range shows that $0.8 \%$ of the participants aged between 61 and 67 are library members, and 3.6\% are not. In the age range of 51 to $60,6.8 \%$ of participants are not library members, but $3.2 \%$ are. In the age range of 41 to $50,9.6 \%$ of participants are not library members, but $7.6 \%$ are. In the age range of 30 to 40 , $15.2 \%$ of participants are not library members, but $16.4 \%$ are. In the age range of 18 to $29,22.4 \%$ of participants are not library members, but $12.8 \%$ are. Of the participants aged up to 18 years old, $0.8 \%$ are not library members, but $0.8 \%$ are.

Within the $41.6 \%$ of library members, results gained using the Likert scale show that $19.6 \%$ of them feel that the library fulfills their current needs, $16.0 \%$ feel that it mostly fulfills their needs, $4.8 \%$ that it neither does nor does not, $0.8 \%$ feel that their library mostly does not fulfill their needs, and $0.4 \%$ feel that it does not (Table 2).

Table 2. Public library members' assessment of the library fulfilling their needs compared to their age

\begin{tabular}{|c|c|c|c|c|c|c|}
\cline { 2 - 7 } \multicolumn{1}{c|}{} & $\begin{array}{c}\text { Non- } \\
\text { members }\end{array}$ & Fulfills & $\begin{array}{c}\text { Mostly } \\
\text { fulfills }\end{array}$ & $\begin{array}{c}\text { Neither } \\
\text { fulfills, } \\
\text { nor does } \\
\text { not }\end{array}$ & $\begin{array}{c}\text { Mostly } \\
\text { does not } \\
\text { fulfill }\end{array}$ & $\begin{array}{c}\text { Doe not } \\
\text { fulfill }\end{array}$ \\
\hline $\begin{array}{c}61-67 \\
\text { years old }\end{array}$ & 3.6 & 0 & 0.4 & 0.4 & 0 & 0 \\
\hline $\begin{array}{c}51-60 \\
\text { years old }\end{array}$ & 6.8 & 1.6 & 1.6 & 0 & 0 & 0 \\
\hline $\begin{array}{c}41-50 \\
\text { years old }\end{array}$ & 9.6 & 5.6 & 1.6 & 0.4 & 0 & 0 \\
\hline
\end{tabular}


za usavršavanjem dodatnih socijalnih vještina kroz timski rad, dok ih 5,2\% ima. U dobnoj skupini od 18 do 29 godina $30,4 \%$ ispitanih nema potrebu, dok ih $4,8 \%$ ima. U dobnoj skupini do 18 godina $1,2 \%$ nema takvu potrebu, a $0,4 \%$ ima.

U kontekstu komunikacijskih i socijalnih vještina zaključujemo da komunikacijom možemo ostvariti sebe (misli, osjećaje, govor), pružiti poruku, ostvariti cilj, dobiti povratnu informaciju od drugih te da su komunikacijske vještine usko povezane sa socijalnim vještinama. Načelno postoje dvije opće vrste komunikacije (verbalna i neverbalna). Komunikacija može biti i interpersonalna, intrapersonalna, grupna, javna, masovna i međukulturna (Reardon 1998). Također, kroz interpersonalnu komunikaciju možemo dati, zatražiti, dobiti ljubav i pažnju, poštovanje drugih, povjerenje, potporu, razumijevanje, ohrabrenje ljudi oko nas, odgovornost (osjećaj samorealizacije), (Brajša 2013).

\section{9. Članstvo u knjižnici i mišljenje ispitanika o njezinoj pomoći građanima}

Od ukupnog udjela rezultati pokazuju da je 58,4\% ispitanih nečlanova knjižnice, tj. građana koji nemaju knjižničnu iskaznicu, dok ih je 41,6 \% član.

U odnosu na starosnu dob korelacijska analiza pokazuje da je u dobnoj skupini od 61 do 67 godina $0,8 \%$ ispitanih član knjižnice, dok ih 3,6\% nije. U dobnoj skupini od 51 do 60 godina 6,8\% ispitanih nije član knjižnice, ali ih 3,2\% jeste. U dobnoj skupini od 41 do 50 godina $9,6 \%$ ispitanih nije član, ali $7,6 \%$ jeste. U dobnoj skupini od 30 do 40 godina $15,2 \%$ ispitanih nije član knjižnice, a 16,4\% jeste. U dobnoj skupini od 18 do 29 godina $22,4 \%$ nije član knjižnice, a 12,8 \% jeste. U dobnoj skupini do 18 godina $0,8 \%$ nije član knjižnice, a $0,8 \%$ jeste.

Unutar cijelog skupa od 41,6\%, rezultati dobiveni Likertovom ljestvicom pokazuju da 19,6\% ispitanika, članova knjižnice, misle da knjižnica ispunjava njihove trenutne potrebe, 16 \% članova knjižnice misli da knjižnica uglavnom ispunjava njihove trenutne potrebe, 4,8\% ispitanih članova misli da njihova knjižnica niti ispunjava, niti ne ispunjava njihove trenutne potrebe, $0,8 \%$ ispitanih mišljenja je da njihova knjižnica uglavnom ne ispunjava njihove trenutne potrebe, a 0,4\% članova misli da ne ispunjava (Tablica 2).

\begin{tabular}{|c|c|c|c|c|c|c|}
\hline $\begin{array}{c}30-40 \\
\text { years old }\end{array}$ & 15.2 & 5.6 & 7.2 & 2.4 & 0.8 & 0.4 \\
\hline $\begin{array}{c}18-29 \\
\text { years old }\end{array}$ & 22.4 & 6.8 & 4.4 & 1.6 & 0 & 0 \\
\hline $\begin{array}{c}\text { up to 18 } \\
\text { years old }\end{array}$ & 0.8 & 0 & 0.8 & 0 & 0 & 0 \\
\hline
\end{tabular}

Member participants' opinions on the opening hours of a public library in a single day mostly $(68.4 \%)$ show that it should be open for users from 8.00 to $20.00,20.4 \%$ think that the library should be open for users from 7.00 to 22.00 , and $11.2 \%$ think that it should be open from 0.00 to 24.00 (Picture 4).

Correlation analysis in comparison to age shows that the need for longer opening hours of the library for users (from 8.00 to 20.00 ) is felt by participants aged 18 to 40 years old ( $4.4 \%$ ), followed by participants aged 41 to 60 years old $(20.0 \%)$.

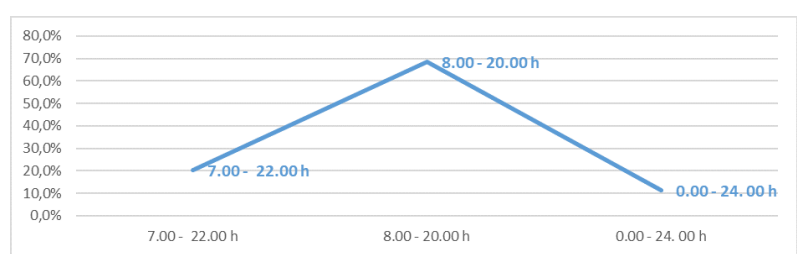

Picture 4. Participants' opinions on the opening hours of libraries for users in a single day

Out of the total number of participants, most of them (32.8\%) think that the library mostly can help in developing a community, $26.8 \%$ thinks it neither can, nor cannot help, $25.2 \%$ think that it can, $4.4 \%$ think that it cannot, and $1.8 \%$ think that it mostly cannot. The answers were given using the Likert scale (Table 3).

Table 3. Participants' assessment of whether the public library can help develop the community

\begin{tabular}{|c|c|c|c|c|}
\hline Cannot & $\begin{array}{c}\text { Mostly } \\
\text { cannot }\end{array}$ & $\begin{array}{c}\text { Neither can, } \\
\text { nor cannot }\end{array}$ & Mostly can & Can \\
\hline 4.4 & 10.8 & 26.8 & 32.8 & 25.2 \\
\hline
\end{tabular}

Out of the total number of participants, most of them $(27.6 \%)$ think that the library cannot help unemployed citizens, followed by participants who think it neither can, nor cannot help $(22.8 \%)$, while $19.6 \%$ think that it mostly cannot help. On the other hand, $13.2 \%$ think that it mostly can help unemployed citizens, and $16.8 \%$ think that it can. The answers were given using the Likert scale (Table 4).

Table 4. Participants' assessment of whether the public library can help unemployed citizens

\begin{tabular}{|c|c|c|c|c|}
\hline Cannot & $\begin{array}{c}\text { Mostly } \\
\text { cannot }\end{array}$ & $\begin{array}{c}\text { Neither can, } \\
\text { nor cannot }\end{array}$ & Mostly can & Can \\
\hline 27.6 & 19.6 & 22.8 & 13.2 & 16.8 \\
\hline
\end{tabular}

In the context of needs: "Attending the enumerated courses on one's own accord is expensive so most unemployed citizens cannot afford it. Earning such a degree comes with a fee in private schools. Sometimes the unemployed candidate can have 
Tablica 2. Procjena članova narodne knjižnice o trenutnom ispunjavanju njihovih potreba u odnosu na starosnu dob

\begin{tabular}{|c|c|c|c|c|c|c|}
\cline { 2 - 7 } \multicolumn{1}{c|}{} & Nečlan & Ispunjava & $\begin{array}{c}\text { Uglavnom } \\
\text { ispunjava }\end{array}$ & $\begin{array}{c}\text { Niti } \\
\text { ispunjava, } \\
\text { niti ne } \\
\text { ispunjava }\end{array}$ & $\begin{array}{c}\text { Uglavnom } \\
\text { ne } \\
\text { ispunjava }\end{array}$ & $\begin{array}{c}\text { Ne } \\
\text { ispunjava }\end{array}$ \\
\hline $\begin{array}{c}61-67 \\
\text { godina }\end{array}$ & 3,6 & 0 & 0,4 & 0,4 & 0 & 0 \\
\hline $\begin{array}{c}51-60 \\
\text { godina }\end{array}$ & 6,8 & 1,6 & 1,6 & 0 & 0 & 0 \\
\hline $\begin{array}{c}41-50 \\
\text { godina }\end{array}$ & 9,6 & 5,6 & 1,6 & 0,4 & 0 & 0 \\
\hline $\begin{array}{c}30-40 \\
\text { godina }\end{array}$ & 15,2 & 5,6 & 7,2 & 2,4 & 0,8 & 0,4 \\
\hline $\begin{array}{c}18-29 \\
\text { godina }\end{array}$ & 22,4 & 6,8 & 4,4 & 1,6 & 0 & 0 \\
\hline $\begin{array}{c}\text { do } 18 \\
\text { godina }\end{array}$ & 0,8 & 0 & 0,8 & 0 & 0 & 0 \\
\hline
\end{tabular}

Mišljenje ispitanika o satnoj otvorenosti narodne knjižnice za korisnike u jednom danu pokazuje da ispitanici u najvećem udjelu $(68,4 \%)$ smatraju da bi narodna knjižnica trebala biti otvorena za rad s korisnicima od 8.00 do 20.00 sati, 20,4 \% ispitanih mišljenja je da bi knjižnica trebala biti otvorena za korisnike od 7.00 do 22.00 sata, $11,2 \%$ misli da bi trebala biti otvorena od 0.00 do 24.00 sata (Slika 4).

Korelacijska analiza u odnosu na starosnu dob pokazuje da potrebu za dužom satnom otvorenošću knjižnice za korisnike (od 8.00 do 20.00) imaju potrebu ispitanici od 18 do 40 godina $(4,4 \%)$, a slijede ih ispitanici od 41 do 60 godina (20\%).

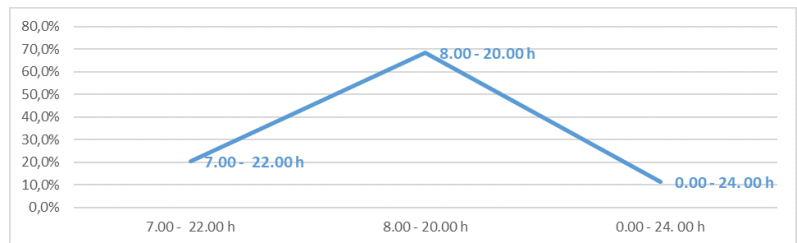

Slika 4. Mišljenje ispitanika o satnoj otvorenosti narodne knjižnice za korisnike u jednom danu

Od ukupnog udjela ispitanih građana, utvrđeno je da najviše ispitanika $(32,8 \%)$ misli da knjižnica uglavnom može pomoći razvoju zajednice, 26,8 \% misli da niti može, niti ne može pomoći, 25,2 \% misli da može, 4,4\% ispitanih misli da ne može, a 1,8 $\%$ da uglavnom ne može. Odgovori su dobiveni Likertovom ljestvicom (Tablica 3).

Tablica 3. Procjena ispitanika o mjeri u kojoj narodna knjižnica može pomoći u razvoju zajednice

\begin{tabular}{|c|c|c|c|c|}
\hline Ne može & $\begin{array}{c}\text { Uglavnom ne } \\
\text { može }\end{array}$ & $\begin{array}{c}\text { Niti može, niti } \\
\text { ne može }\end{array}$ & $\begin{array}{c}\text { Uglavnom } \\
\text { može }\end{array}$ & Može \\
\hline 4,4 & 10,8 & 26,8 & 32,8 & 25,2 \\
\hline
\end{tabular}

Od ukupnog udjela ispitanih građana Likertovom ljestvicom utvrđeno je da najviše ispitanika $(27,6$ \%) misli da knjižnica ne može pomoći nezaposlenim osobama. Slijede ih ispitanici koji misle da niti može, niti ne može pomoći (22,8 \%), dok 19,6 \% ispitanih misli da uglavnom ne može. S druge strane, basic knowledge of something but does not have a diploma as proof and can therefore remain noncompetitive for a job vacancy. The problem appears if the candidate possesses a certain level of knowledge in the initial phase of unemployment but loses it through long-term lack of use due to unemployment" (Zubac 2019, 31).

Greene Taylor et al. $(2012,196)$ state that less privileged citizens in the USA are often not in a position to continue their educations after finishing high school even though the academic community is trying to adjust to the changes in education. They point out that adults who finished the standard education according to their times have outdated skills and lack of means to achieve higher education.

For public libraries to be capable of fulfilling the needs of all the citizens within its community and influence the quality of life of its citizens, namely socially excluded, unemployed citizens, they must firstly increase their opening hours for users within a single day, decrease membership fees and offer new services, programs and activities, as well as recognize the importance of marketing and management. Increasing the opening hours of a library for users in a single day often requires employing new competent staff, which should be kept in mind by library founders (cities and municipalities). This only confirms Peterman and Williment's (2013) claim that public libraries are only superficially open for everyone. Žero $(2020,21)$ points out that in the technological sense "there is need for more support by society in order for libraries to catch up with current trends in librarianship." Besides gaining competitive skills, the enumerated needs can help a citizen become competitive on the labor market and help them find a job.

Zubac $(2019,237)$ says that it is desirable for ever public library to have a webpage with clearly stated notifications on the library's business and employees.

In terms of results, there is a logical inconsistency as citizens declared a need for lifelong learning, while at the same time stating the complete opposite to offered services. Such inconsistencies may be interpreted in several ways: firstly, the participants have needs other than those stated in the research. Secondly, the participants have a need for lifelong learning, but the offered services in libraries are unknown as public libraries generally do not offer such services in Croatia. Thirdly, a great number of participants are not members of libraries, and as such cannot generally make use of other services without a membership card.

Aabø (2015) is of the opinion that the value of a public library depends on how successfully it performs its roles, i.e. how well it fulfills the needs of its community and how valued they are by the citizens and the community it serves. 
13,2 \% ispitanika misli da narodna knjižnica uglavnom može pomoći nezaposlenim građanima, a 16,8 \% kaže da može (Tablica 4).

Tablica 4. Procjena ispitanika o mjeri u kojoj narodna knjižnica može pomoći nezaposlenim osobama

\begin{tabular}{|c|c|c|c|c|}
\hline Ne može & $\begin{array}{c}\text { Uglavnom } \\
\text { ne može }\end{array}$ & $\begin{array}{c}\text { Niti može, } \\
\text { niti ne } \\
\text { može }\end{array}$ & $\begin{array}{c}\text { Uglavnom } \\
\text { može }\end{array}$ & Može \\
\hline 27,6 & 19,6 & 22,8 & 13,2 & 16,8 \\
\hline
\end{tabular}

U kontekstu potreba: "Pohađanje nabrojenih tečajeva prema vlastitom nahođenju je skupo pa si ih većina nezaposlenih građanina ne može priuštiti. Dobivanje takve vrste diplome naplaćuje se u privatnim školama. Ponekad nezaposleni kandidat posjeduje temeljno znanje iz nečega, ali nema potrebnu diplomu kao dokaz pa, kao takav, može postati nekonkurentan na natječaju za posao. Problem se javlja ako kandidat posjeduje određeni stupanj znanja u početnoj fazi nezaposlenosti, ali ga kroz dugoročnu nezaposlenost ne koristi pa ono blijedi." (Zubac 2019, 31)

Greene Taylor et al. $(2012,196$.$) kažu da manje$ imućni građani u SAD-u često nisu u mogućnosti nastaviti daljnje školovanje nakon završene srednje škole iako se akademska zajednica trudi prilagoditi promjeni u obrazovanju. Ističe da odrasli koji su završili uobičajeno obrazovanje u skladu sa svojim vremenom imaju zastarjele vještine i nerijetko nedovoljno sredstva za postizanje visokog obrazovanja.

Da bi narodne knjižnice mogle ispuniti potrebe svih građana svoje zajednice i utjecati na kvalitetu života svojih građana, a u ovom slučaju društveno isključenih nezaposlenih građana, one prije svega moraju povećati satnu otvorenost knjižnice za rad s korisnicima u jednome danu, smanjiti članarine te ponuditi nove usluge, programe i aktivnosti, kao i prepoznati važnost marketinga i menadžmenta. Povećanje satne otvorenosti knjižnice za rad s korisnicima u jednome danu, nerijetko zahtijeva i nova zapošljavanja kompetentnih djelatnika, što bi osnivači knjižnica (gradovi i općine) trebali imati u vidu. Ovaj podatak potvrđuje Petermanovu i Willimentovu (2013) tvrdnju da su narodne knjižnice trenutno samo površno otvorene za sve. U tehnološkom kontekstu Žero $(2020,21)$ ističe da je "potrebna veća podrška društva kako bi biblioteke uhvatile korak sa savremenim trendovima u bibliotekarstvu". Upravo ispitane potrebe uz stjecanje kompetentnih vještina mogu građaninu omogućiti konkurentnost na tržištu rada i pomoći mu da pronađe posao.

Zubac $(2019,237)$ kaže da je poželjno da svaka narodna knjižnica ima web stranicu s jasno uređenim obavijestima o poslovanju knjižnice i zaposlenicima. Po pitanju rezultata uočena je logička nedosljednost jer građani imaju potrebu za cjeloživotnim učenjem, a na ponuđene usluge su u najvećem udjelu

\section{Conclusion}

The aim of this paper was to present the results of the research on the needs of unemployed citizens in the Osijek-Baranja County with the purpose of improving the knowledge of advancing the services, programs, and activities of public libraries, as well as the quality of life of unemployed citizens.

Results of the research show that socially excluded, unemployed citizens, especially those in the ages of 30 to 40 years old have different needs in terms of lifelong learning, and that not all socially excluded, unemployed citizens exclusively depend on visiting public libraries for internet access, which is the role a library primarily serves in an informational-technological society.

The most important results of the research show that the tested citizens have a need for learning within programs of lifelong learning. On the other hand, they stated in a large majority that they do not have such needs in libraries. When analyzing the results, a logical inconsistency was noted as citizens declared a need for lifelong learning, while at the same time stating the complete opposite to offered services. Such inconsistencies may be interpreted in several ways: firstly, the participants have needs other than those stated in the research. Secondly, the participants have a need for lifelong learning, but the offered services in libraries are unknown as public libraries generally do not offer such services in Croatia. Thirdly, a great number of participants are not members of libraries, and as such cannot generally make use of other services without a membership card.

The most pronounced needs of tested citizens are the need to learn English and German; computer and technical skills; the need for perfecting communicational skills; perfecting additional social skills through teamwork, learning work etiquette, gaining organizational skills, promotional skills, and learning nonverbal communication or body language. Results show that despite a portion of the participants $(41.6 \%)$ being library members, they still have other needs within lifelong learning which are not met by their libraries. Results also show that not all public libraries in the Osijek-Baranja County are open for the entire day for all users. Unemployed, socially excluded citizens are of the opinion that a public library can help develop their community but cannot help the unemployed citizens themselves. Given that the public library is open to all, none of the stated citizens' needs can be disregarded.

In fact, if public libraries want to meet the needs of their users and improve the quality of life, they should primarily focus on improving the competence of their employees, get out of their comfort zone, and provide specific services to unemployed people. They should recognize the seriousness of the prob- 
odgovorili suprotno. Te nedosljedne razlike mogu se protumačiti na više načina: prvo, ispitanici imaju neke druge potrebe koje nisu bile obuhvaćene istraživanjem; drugo ispitanici imaju potrebu za cjeloživotnim učenjem, ali su ponuđene usluge u knjižnici nepoznate jer narodne knjižnice u Hrvatskoj ovakve usluge u pravilu ne nude. Treće, veliki broj ispitanih građana nije član knjižnice, a ako ispitanici ne posjeduju člansku knjižničnu iskaznicu, u pravilu ne smiju ni koristiti šire usluge.

Aabø (2005) je mišljenja da vrijednost narodnih knjižnica ovisi o tome koliko uspješno obavljaju svoju ulogu, odnosno koliko ispunjavaju potrebe svojih zajednica te koliko ih vrednuju građani i zajednice kojima služe.

\section{Zaključak}

Cilj rada bio je predstaviti rezultate istraživanja o potrebama nezaposlenih građana Osječko-baranjske županije u svrhu unapređenja spoznaja o poboljšanju službi, usluga, programa i aktivnosti narodnih knjižnica te utjecaja na kvalitetu života nezaposlenih građana.

Iz rezultata istraživanja vidljivo je da društveno isključeni nezaposleni građani, posebice oni u dobnim skupinama od 30. do 40. godine starosti imaju različite potrebe u sastavu cjeloživotnog obrazovanja te da svi društveno isključeni građani po pitanju pristupa internetu ne ovise isključivo o posjeti narodnoj knjižnici i njezinoj usluzi koju ona primarno nudi u informacijsko-tehnološkom društvu.

Najvažniji rezultati istraživanja pokazali su da ispitani građani imaju potrebu za učenjem u sastavu cjeloživotnog obrazovanja. S druge strane, u najvećem ukupnom postotku na ponuđena pitanja izjasnili su se da nemaju potrebe u knjižničnom prostoru. Pri obradi rezultata uočena je logička nedosljednost jer građani imaju potrebu za cjeloživotnim učenjem, a na ponuđene usluge su u najvećem udjelu odgovorili suprotno. Te nedosljedne razlike mogu se protumačiti na više načina: prvo, ispitanici imaju neke druge potrebe koje nisu bile obuhvaćene istraživanjem, ispitanici imaju potrebu za cjeloživotnim učenjem, ali su ponuđene usluge u knjižnici nepoznate jer narodne knjižnice u Hrvatskoj ovakve usluge u pravilu ne nude. Treće, veliki broj ispitanih građana nije član knjižnice, a ako ispitanici ne posjeduju člansku knjižničnu iskaznicu, u pravilu ne smiju ni koristiti šire usluge.

Najizraženije potrebe ispitanih građana jesu potrebe za učenjem engleskoga i njemačkoga jezika; računalnim i tehničkim vještinama, potreba za usavršavanjem komunikacijskih vještina; usavršavanjem dodatnih socijalnih vještina kroz timski rad, upoznavanje pravila poslovnog bontona, stjecanje organizacijskih vještina, promocijskih vještina, učenje lem, the importance of developing new operational programs, strategic business planning, improving cooperation with local, regional, and the community at large, providing marketing, advocacy, and advertising services in the community that can contribute to better inclusion and cohesiveness of citizens. They should also involve volunteers from different professions or hire external associates if their employees do not have the necessary skills to perform specific services or hire competent staff, increase the library's business hours, reduce membership fees, collaborate as a partner on EU-funded projects or apply for their programs on tenders and receive earmarked funds for work and continuously implement such projects, cross-border cooperation with other libraries on this topic and projects and more. The synergistic circle of providing quality library services, recognizing the importance of the public library in the community leads to human and social capital that contributes to the sustainable social development of the community.

Otherwise, they will remain only superficially open to all citizens in their communities, making it hard to talk about true social inclusion or cohesion, as well as the need for solidarity and tolerance. 
neverbalne komunikacije ili govora tijela. Rezultat istraživanja pokazao je da, unatoč tomu što je dio ispitanika (41,6 \%) član narodne knjižnice, i dalje ima različite potrebe u sastavu cjeloživotnog obrazovanja, a njihova im knjižnica ne pruža mogućnost ispunjavanja.

Pokazao je $\mathrm{i}$ to da nisu sve narodne knjižnice $\mathrm{u}$ Osječko-baranjskoj županiji cjelodnevno otvorene za sve korisnike. Nezaposleni, društveno isključeni građani mišljenja su da narodna knjižnica može pomoći u razvoju zajednice, ali ne može nezaposlenim osobama. Budući da je narodna knjižnica ustanova otvorena za sve, niti jedna od navedenih potreba građana ne bi smjela biti zanemarena.

Ističemo, ako narodne knjižnice žele izaći u susret korisnicima i utjecati na kvalitetu života svojih građana, trebale bi, prije svega, poboljšati generičku kompetentnost svojih zaposlenika, izaći iz zone komfora i pružiti specifične usluge nezaposlenim građanima. Trebale bi prepoznati ozbiljnost problema, važnost izrade novih operativnih programa, strateško planiranje poslovanja; poboljšanu suradnju s lokalnom, regionalnom i širom zajednicom; poboljšati pružanje usluga marketinga, zagovaranje i oglašavanje u zajednici, što može pridonijeti boljoj inkluzivnosti i kohezivnosti građana: uključiti volontere iz različitih struka ili zaposliti vanjske suradnike ako njihovi zaposlenici nemaju potrebne vještine za provođenje specifičnih usluga ili prilikom zapošljavanja zapošljavati kompetentno osoblje, povećati satnu otvorenost knjižnice za rad s korisnicima u jednome danu, smanjiti članarine, surađivati kao partner na projektima iz europskih fondova Europske unije ili samostalno aplicirati vlastite programe na natječaje i dobiti namjenska sredstva za rad te kontinuirano provoditi ovakve projekte, prekogranično surađivati s ostalim knjižnicama u pitanju ove tematike i projekata i dr.

Sinergijski krug pružanja kvalitetnih knjižničnih usluga, prepoznavanje važnosti narodne knjižnice u zajednici dovodi do ljudskog i društvenog kapitala koji doprinosi kvalitetnom održivom društvenom razvoju zajednice.

U suprotnom, one će i dalje ostati površno otvorene za sve građane u zajednici u kojoj djeluju pa je o istinskoj društvenoj inkluziji i koheziji teško govoriti, kao i potrebi za solidarnošću i tolerantnošću.

\section{Literatura / Bibliography}

Aabø, Svanhild. 2005. "The role and value of public libraries in the age of digital technologies" Journal of Librarianship and Information Science 37 (4). DOI: https://doi. org/10.1177/0961000605057855.

Australian Library and Information Association. 2014. "Future of the library and information science profession". Canberra: ALIA. https:// www.alia.org.au/sites/de fault/files/ALIAFuture-of-the-LIS-Profession-01_0.pdf.

Brajša, Pavao. 2013. Bez razgovora se ne može: Kvalitetnijim razgovorom do sebe $i$ drugih. Zagreb: Glas Koncila.

European Commision. 2018. "The European Entrepreneurship Competence Framework (EntreComp)". Posljednja izmjena: 11. mart. https://ec.europa.eu/social/main. jsp?catId=1317\&langId=en.

European Commision. 2015. "The Education \& Training Monitor 2015: how public libraries help to meet EU: blog". Posljednja izmjena: 15. februar 2016. prioritieshttp://ec.europa. $\mathrm{eu} / \mathrm{epale} / \mathrm{en} / \mathrm{blog} /$ education-training-monitor2015-how-public-libraries-help-meet-eu-priorities.

Eurostat. 2017. "Euro area unemployment at 9.5\%". Posljednja izmjena: 2. maj $2017 . \quad \mathrm{http} / / /$ ec.europa.eu/eurostat/ documents/2995521/8002525/3-02052017AP-EN.pdf/94b69232-83a9-4011-8c85$1 \mathrm{~d} 4311215619$.

Greene Taylor, Natalie, Paul T. Jaeger, Abigail J. McDermott, Christie M. Kodama, and John Carlo Bertot. 2012. "Public Libraries in the New Economy: Twenty-First-Century Skills, the Internet, and Community Needs" Public Library Quarterly 31 (3). DOI: https://doi.or $\mathrm{g} / 10.1080 / 01616846.2012 .707106$.

Hibert, Mario. 2012. "Kritičko bibliotekarstvo: moguća paradigma informacijskog društva" Doktorska disertacija, Filozofski fakultet Sveučilišta u Zagrebu.

Hrvatski zavod za zapošljavanje. Statistika. Posljednja izmjena: 7. august 2017. http://statistika. hzz.hr/statistika.aspx?tipIzvjestaja $=1$.

Huysmans, Frank, and Marjolein Oomes. 2013. "Measuring the public library's societal value: A methodological research program" International Federation of Library Associations and Institutions 39 (2). DOI: https://doi. org/10.1177/0340035213486412.

James V. Brown Library, 19 E. Fourth St. "Explore free job and career resources through the Brown Library". Posljednja izmjena: 28. 
aprila 2017. https://jvbrown.edu/explorefree-job-and-career-resources-through-thebrown-library/.

Kathleen Kathleen. 1998. Interpersonalna komunikacija. Zagreb: Alinea.

Lloyd, Annemaree. 2010. Information Literacy Landscapes: Information Literacy in Education, Workplace and Everyday Contexts. 1st Edition. Oxford (UK): Chandos Publishing.

Martinović, Ivana, Boris Badurina, Matea Zuzjak. 2016. "Contribution of Public Libraries to the increase of Digital Inclusion in the Osijek-Baranya County" U 5. međunarodni znanstveni simpozij Gospodarstvo istočne Hrvatske: vizija i razvoj / 5th International Scientific Symposium Economy of Eastern Croatia: vision and growth, uredila Anka Mašek Tonković, 477-484. Osijek: Sveučilište Josipa Jurja Strossmayera u Osijeku, Ekonomski fakultet u Osijeku.

Mastalio, Christine. 2010. "Developing Career Resources in Public Libraries". Posljednja izmjena: 9. februar 2016. file://D:/Dokumenti/ Downloads/Developing\%20Career\%20Resources\%20in\%20Public\%20Libraries.pdf.

McCallum E., R. Weicht, L. McMullan, and A. Price. 2018. "EntreComp into Action: get inspired, make it happen" U EUR 29105 EN, Publications Office of the European Union, Luxembourg, Eds. M. Bacigalupo and W. O'Keeffe, DOI: $10.2760 / 574864$, JRC109128.

Peterman, John, and Ken Williment. 2013. Developing Community - Led Public Libraries: Evidence from the UK and Canada. UK: Routledge. https:// Taylor \& Francis Group. Datum pristupa: 11. 9. 2017.

Scott, Rachel. 2011. "The Role of Public Libraries in Community Building" Public Library Quarterly 30 (3). DOI: https://doi.org/10.1080/0 1616846.2011.599283.

Skrzeszewski, Stan, and Maureen Cubberley. 1997. "Community-based economic development and the library - a concept paper" Library Management 18 (7). DOI: http://dx.doi. org/10.1108/01435129710170379

Slatter, Diane, and Zaana Howard. 2013. "A place to make, hack, and learn: makerspaces in Australian public libraries" The Australian Library Journal 62 (4). DOI: 10.1080/00049670.2013.853335.

Šporer, Željka. 2004. "Koncept društvene isključenosti” Društvena istraživanja 13 (1/2). URL: https://hrcak.srce.hr/16108.

Šućur, Zoran. 2016. "Socijalna isključenost i soci- jalna pravednost: Znanstveno-stručni skup Socijalno inkluzivne usluge". Posljednja izmjena: 18. novembra 2016. www.knjiznica-koprivnica.hr/knjiznica/Dokumenti/1. SUCUR Z.ppt.

UN. 2015. "Agenda Ujedinjenih naroda za održivi razvoj 2030". Posljednja izmjena: 5. maja 2017. https://sustainabledevelopment.un.org/ post2015/transformingourworld.

United Nations General Assembly. 2016. "Human Rights Council thirty-second session, agenda item 3: promotion and protection of all human rights, civil, political, economic, social and cultural rights, including the right to development". Posljednja izmjena: 5. maja 2017. https://www.article19.org/data/files/Internet_Statement_Adopted.pdf.

UNESCO. 2014. Roadmap for Implementing the Global Action Programme on Education for Sustainable Development. Paris.

Vujčić, Boris. 2016. "Ljudski kapital i ekonomski rast u Hrvatskoj: Kako brže naprijed?". Posljednja izmjena: 9. jun 2016. https://www. hnb.hr/-/ljudski-kapital-i-ekonomski-rast-uhrvatskoj-kako-brze-naprijed-.

Wu, Mei Mei. 2018. "Social Inclusion - Study of the Homeless Users in the Public Library in Taipei Wanhwa District" U Can the library do everything? The changing role of librarians and the library as a space of social inclusion [Webinar : Facebook]. IFLA New Professionals Special Interest Group, IFLA Continuing Professional Development and Workplace Learning and the American Library Association. Posljednja izmjena: 16. april 2018. https://www.facebook.com/npsig/?hc ref=ARQ71M6wiSlzVh88qsq9HGue31r e I n 2 U O R Z W V W A N b a Y 3 b _ zTXvzpWq2i4ZvHFBhWxE\&fref=nf.

Quick, Susannah, Gillian Prior, Ben Toombs, Luke Taylor, and Rosanna Currenti. 2013. "Europaweite Umfrage zu den Vorteilen von Informations- und Kommunikationssystemen in öffentlichen Bibliotheken aus Sicht der Nutzer". Posljednja izmjena: 26. maja 2016. https://digital.lib.washington.edu/researchworks/bitstream/handle/1773/23995/TNS_CrossEuropean_German.pdf? sequence $=1$.

Zubac, Andreja. 2019. "Model knjižničnih usluga za nezaposlene osobe" Doktorska disertacija, Filozofski fakultet Sveučilišta u Zagrebu.

Žero, Adisa. 2020. "Javne biblioteke i komunikacijske tehnologije" U Vodič kroz javne biblioteke. Sarajevo: Nacionalna i univerzitetska biblioteka Bosne Hercegovine. 